\title{
Abundant Expression of OCT2, MATE1, OAT1, OAT3, PEPT2, BCRP, MDR1, and XCT Transporters in Blood-Arachnoid Barrier of Pig and Polarized Localizations at CSF- and Blood-Facing Plasma Membranes ${ }^{\sqrt{\text { }}}$
}

\author{
(1) Yasuo Uchida, Ryohei Goto, Hina Takeuchi, Magdalena Łuczak, Takuya Usui, \\ Masanori Tachikawa, and Tetsuya Terasaki
}

Graduate School of Pharmaceutical Sciences (Y.U., M.t., T.U., M.T., T.T.) and Faculty of Pharmaceutical Sciences (Y.U., R.G., H.T., M.T., T.T.), Tohoku University, Sendai, Japan; and Institute of Bioorganic Chemistry, Polish Academy of Sciences, Warsaw, Poland (M.t.)

Received September 26, 2019; accepted November 19, 2019

\section{ABSTRACT}

The physiologic and pharmacologic roles of the blood-arachnoid barrier (BAB) remain unclear. Therefore, the purpose of the present study was to comprehensively evaluate and compare the absolute protein expression levels of transporters in the leptomeninges and plexus per cerebrum, and to determine the localizations of transporters at the cerebrospinal fluid (CSF)-facing and blood (dura)facing plasma membranes of the $B A B$ in pig. Using multidrug resistance protein 1 (MDR1) and organic anion transporter (OAT) 1 as blood (dura)-facing and CSF-facing plasma membrane marker proteins, respectively, we established that breast cancer resistance protein (BCRP), multidrug resistance-associated protein (MRP) 4, organic anion-transporting polypeptide (OATP) 2B1, multidrug and toxin extrusion protein 1 (MATE1), and glucose transporter 1 (GLUT1) are localized at the blood-facing plasma membrane, and OAT3, peptide transporter (PEPT) 2, MRP3, organic cation transporter (OCT) 2, xCT, monocarboxylate transporter (MCT) 1, MCT4, and MCT8 are localized at the CSF-facing plasma membrane of the BAB. The absolute protein expression levels of OAT1, OAT3, MDR1, BCRP, PEPT2, xCT, MATE1, OCT2, and 4f2hc in the whole BAB surrounding the entire cerebrum were much larger than those in the total of the choroid plexuses forming the blood-cerebrospinal fluid barrier (BCSFB). Although MRP4, OATP2B1, MCT8, GLUT1, and $M C T 1$ were also statistically significantly more abundant in the BAB than in the choroid plexuses per porcine cerebrum, these transporters were nevertheless almost equally distributed between the two barriers. In contrast, OATP1A2, MRP1, OATP3A1, and OCTN2 were specifically expressed in the choroid plexus. These results should be helpful in understanding the relative overall importance of transport at the BAB compared with that at the BCSFB, as well as the rank order of transport capacities among different transporters at the $B A B$, and the directions of transport mediated by individual transporters.

\section{SIGNIFICANCE STATEMENT}

We found that BCRP, MRP4, OATP2B1, MATE1, and GLUT1 localize at the blood-facing plasma membrane of the blood-arachnoid barrier (BAB), while OAT3, РEPT2, MRP3, ОСT2, XCT, MCT1, MCT4, and МСT8 localize at the CSF-facing plasma membrane. 4F2hc is expressed in both membranes. For OAT1, OAT3, MDR1, BCRP, PEPT2, XCT, MATE1, OCT2, and $4 \mathrm{f} 2 \mathrm{hc}$, the absolute protein expression levels in the whole BAB surrounding the entire cerebrum are much greater than the total amounts in the choroid plexuses.
This study was supported in part by Grants-in-Aids from the Japanese Society for the Promotion of Science for Young Scientists (A) [KAKENHI Grant 16H06218], Scientific Research (B) [KAKENHI Grant 17H04004], Bilateral Open Partnership Joint Research Program (between Finland and Japan), Fostering Joint International Research (A) [KAKENHI Grant 18KK0446], and Early-Career Scientists [KAKENHI Grant 19K16438]. This study was also supported in part by Grants-in-Aids from the Ministry of Education, Culture, Sports, Science and Technology for Scientific Research on Innovative Areas [KAKENHI Grant 18H04534], and the Mochida Memorial Foundation for Medical and Pharmaceutical Research. M.t. was supported by a Research Fellowship Program (2019) from Matsumae International Foundation.

T.T. is a full professor at Tohoku University, and also a director of Proteomedix Frontiers Co., Ltd. This study was not supported by Proteomedix Frontiers Co., Ltd., and his position at Proteomedix Frontiers Co., Ltd. did not influence the design of the study, the collection of the data, the analysis or interpretation of the data, the decision to submit the manuscript for publication, or the writing of the manuscript and did not present any financial conflicts. The other authors declare no competing interests.

https://doi.org/10.1124/dmd.119.089516.

$\$$ This article has supplemental material available at dmd.aspetjournals.org.

\section{Introduction}

Studies of the central nervous system (CNS) barriers have often focused on the blood-brain barrier (BBB). However, many aspects of substance exchange between the peripheral blood and CNS cannot be explained solely in terms of the transport systems at the BBB. The arachnoid membrane covers the cerebrospinal fluid (CSF) in the subarachnoid space, which contains about $80 \%$ of the total CSF volume (Thorne, 2014). The arachnoid membrane consists of arachnoid epithelial cells linked by tight junctions, and is called the blood-arachnoid barrier (BAB). The epithelial cells have polarized dual plasma membranes on the blood (dura)- and CSFfacing sides. Although the leptomeninges consist of arachnoid membrane, pia mater, and subarachnoid space containing the CSF, only the arachnoid membrane forms tight junctions and serves to separate the CSF and circulating blood sides. Yasuda et al. (2013) reported that multiple transporters are expressed in leptomeninges at the mRNA level, and we subsequently found that oat 3 and 
oatp1a4 contribute to the elimination of anionic compounds from the CSF in rodents (Zhang et al., 2018; Yaguchi et al., 2019). Therefore, the BAB may be a major elimination route for organic anions from the CNS. However, it is not clear whether the results obtained in rodent studies adequately reflect the role of the BAB in large animals, including human beings, because large interspecies differences have been found in the protein expression levels of transporters (Kubo et al., 2015). Not only organic anions, but also neurotoxic cations produced in the CNS [creatinine, $\mathrm{N}$-methylnicotinamide (NMN), etc.] are eliminated from the CNS. For example, large amounts of creatinine are produced from creatine in the brain, but cannot be eliminated via the BBB. Nevertheless, the subarachnoid CSF concentration is much lower than the brain concentration in humans (Marescau et al., 1992; De Deyn et al., 2001), so it is plausible that creatinine may be mainly eliminated from the CSF at the BAB. However, it is not yet known which cation transporters are expressed at the $\mathrm{BAB}$.

Substance exchange between CSF and blood is known to be mediated via the blood-cerebrospinal fluid barrier (BCSFB), which consists of choroid plexus epithelial cells. It is crucial to clarify the functional significance of the transport systems of the $\mathrm{BAB}$, compared with those of the BCSFB, to understand the physiologic role of the BAB. Since our first report on quantitative targeted absolute proteomics (qTAP) (Kamiie et al., 2008), we have quantified multiple proteins (including transporters, enzymes, and receptors) in plasma membrane fractions prepared from a variety of tissues and cells using protein concentration units of femtomole per $1 \mu \mathrm{g}$ protein of plasma membrane fraction (femtomoles per microgram protein) (Ohtsuki et al., 2012, 2013; Uchida et al., $2015 \mathrm{a}, \mathrm{b})$. We also recently employed this unit to compare the protein concentrations of transporters in the plasma membrane fractions of leptomeninges and choroid plexus in rat (Zhang et al., 2018). However, neither losses of plasma membrane during plasma membrane preparation nor the relative whole-tissue amounts of leptomeninges and choroid plexuses were taken into account. Thus, the relative transport contributions of the whole $\mathrm{BAB}$ in one brain and the whole BCSFB of four ventricles remain unclear. To more deeply understand the physiologic roles of the $\mathrm{BAB}$ and $\mathrm{BCSFB}$, we also need to investigate the differences in the transport systems of the $\mathrm{BAB}$ among different lobes of the brain, as well as those in the BCSFB among different ventricles.

Another important issue is to clarify the membrane localizations of transporters in the $\mathrm{BAB}$. Whether the $\mathrm{BAB}$ contributes to CSF-to-blood efflux or blood-to-CSF influx of substances would depend on whether transporters are localized at the CSF-facing or blood (dura)-facing plasma membranes. Interestingly, an immunostaining study indicated that breast cancer resistance protein (BCRP), an efflux transporter of xenobiotics, is expressed on both sides of plasma membranes in arachnoid epithelial cells (Yasuda et al., 2013). This was a dramatic finding because BCRP is always localized at the apical (luminal) membrane in other tissue barriers. Therefore, the membrane localizations of transporters at the $\mathrm{BAB}$ may be different from those in the $\mathrm{BCSFB}$ and $\mathrm{BBB}$, and establishing the differences may be the key to understanding the role of $\mathrm{BAB}$.

Thus, the purpose of the present study was to clarify the absolute abundances of a wide range of transporters at the whole $\mathrm{BAB}$ and whole $\mathrm{BCSFB}$ in porcine cerebrum, as well as the regional differences among the four different cerebral lobes and four ventricles, by means of qTAP.
We also aimed to clarify the CSF-facing/blood-facing membrane localizations of transporters at the BAB. For the present study, we selected the pig as a target animal because porcine biology, including genome, anatomy, physiology, and disease progression, reflects human biology more closely than is the case for many other experimental animals (Walters et al., 2011; Patabendige et al., 2013) and porcine tissues are readily available compared with tissues of other large animals.

\section{Materials and Methods}

Materials. Unlabeled (standard) and stable isotope-labeled (internal standard) peptides for quantifying targeted proteins were designed by using the in silico peptide selection criteria that we reported previously (Kamiie et al., 2008) and were synthesized by SCRUM Inc. (Tokyo, Japan) and Thermo Fisher Scientific (Sedanstrasse, Germany) with $>95 \%$ peptide purity. The concentrations of peptide solutions were quantified by quantitative amino acid analysis using a high-performance liquid chromatography UV system with postcolumn ninhydrin derivatization (LaChrom Elite; Hitachi, Tokyo, Japan). Other chemicals used were commercial products of analytical grade.

Porcine brain tissues isolated from healthy pigs at about 6 months after birth $(100-120 \mathrm{~kg}$ of body weight, male:female $=1: 1$, without any drug treatment) were purchased from Tokyo Sibaura Zouki Inc. (Tokyo, Japan). The protocols for the present study were approved by the Livestock Hygiene Service Center authorized by the Ministry of Health, Labor and Welfare, and the Ministry of Agriculture, Forestry and Fisheries in Japan.

Preparation of Plasma Membrane Fraction and Whole-Tissue Lysate of Porcine Leptomeninges and Choroid Plexus and the Experimental Parameters Used for Unit Conversions of Protein Expression Level. The leptomeninges were isolated separately from the frontal, parietal, occipital, and temporal lobes of porcine cerebrum. Choroid plexuses were isolated separately from the right-lateral, left-lateral, third, and fourth ventricles of porcine brain. The tissue weights of all leptomeninges and the choroid plexus of each ventricle from one porcine cerebrum and the weight of $1 \mathrm{~cm}^{2}$ leptomeninges were measured (Supplemental Table 1). For each region of leptomeninges and choroid plexus, tissue of a specific weight (described as tissue weight used for plasma membrane preparation in Supplemental Table 1) was used for the preparation of whole-tissue lysate. Subsequently, almost all of the prepared whole-tissue lysate (except for a part of this lysate used for the proteomics experiment) were used for plasma membrane preparation. The plasma membrane fractions were prepared as described previously (Uchida et al., 2015b). The protein concentrations of whole-tissue lysate and plasma membrane fraction were determined by the Lowry method, which are summarized in Supplemental Table 1, together with the volume of solution used to dissolve whole-tissue lysate and plasma membrane fraction. The protein expression levels of the following marker proteins in the whole-tissue lysate and plasma membrane fraction were determined by means of qTAP, as described subsequently. Anion exchanger 2 (AE2) and organic anion transporter (OAT) 1 are specifically expressed at the plasma membrane of epithelial cells in choroid plexus and leptomeninges, respectively (Christensen et al., 2013; Zhang et al., 2018). They were used as marker proteins in quantifications of choroid plexus and leptomeninges samples, respectively (Supplemental Table 1). These experimental parameters were used for unit conversions of protein expression levels, as described subsequently. The plasma membrane fractions and whole-tissue lysates were stored at $-80^{\circ} \mathrm{C}$.

Separation of CSF- and Blood-Facing Plasma Membranes of Arachnoid Epithelium from Porcine Leptomeninges by Density-Gradient Ultracentrifugation. The isolated leptomeninges from porcine whole cerebrums were minced well with scissors on ice and homogenized in hypotonic buffer $[10 \mathrm{mM}$ Tris- $\mathrm{HCl}, 10 \mathrm{mM} \mathrm{NaCl}$, and $1.5 \mathrm{mM} \mathrm{MgCl}_{2}$ (pH 7.4)], using a Potter-Elvehjem glass homogenizer (10 up-and-down strokes with rotation at $1000 \mathrm{rpm}$ and $4^{\circ} \mathrm{C}$ ).

ABBREVIATIONS: AE2, anion exchanger 2; BAB, blood-arachnoid barrier; BBB, blood-brain barrier; BCRP, breast cancer resistance protein; BCSFB, blood-cerebrospinal fluid barrier; CNS, central nervous system; CSF, cerebrospinal fluid; GLUT1, glucose transporter 1; MATE1, multidrug and toxin extrusion protein 1; MCT, monocarboxylate transporter; MDR1, multidrug resistance protein 1; MRP, multidrug resistance-associated protein; NMN, N-methylnicotinamide; OAT, organic anion transporter; OATP, organic anion-transporting polypeptide; OCT, organic cation transporter; PEPT, peptide transporter; P-gp, P-glycoprotein; qTAP, quantitative targeted absolute proteomics; SWATH, sequential window acquisition of all theoretical; TFA, trifluoroacetic acid. 
After incubation for 30 minutes on ice, 20 up-and-down strokes were applied with rotation at $1000 \mathrm{rpm}$ and $4^{\circ} \mathrm{C}$. The resulting homogenate was subjected to nitrogen cavitation twice at $1500 \mathrm{psi}$ for 15 minutes at $4^{\circ} \mathrm{C}$. The homogenate thus obtained was centrifuged twice at $10,000 \mathrm{~g}$ for 10 minutes at $4^{\circ} \mathrm{C}$ and the resulting supernatant was centrifuged at $100,000 \mathrm{~g}$ for 40 minutes at $4^{\circ} \mathrm{C}$. The pellet was suspended in suspension buffer [ $10 \mathrm{mM}$ Tris- $\mathrm{HCl}$ and $250 \mathrm{mM}$ sucrose ( $\mathrm{pH}$ 7.4)], layered on top of a $24 \% / 27 \% / 30 \%(\mathrm{w} / \mathrm{v})$ sucrose density gradient solution, and centrifuged at $195,700 \mathrm{~g}$ for 3 hours at $4^{\circ} \mathrm{C}$. The three turbid layers at the interfaces (first layer, top/24\%; second layer, 24\%/27\%; third layer, 27\%/30\%) were recovered and each was suspended in suspension buffer and centrifuged at $100,000 \mathrm{~g}$ for 40 minutes at $4^{\circ} \mathrm{C}$. The resultant pellets were suspended in the suspension buffer to obtain the individual membrane fractions. The Lowry method with the DC Protein Assay Reagent (Bio-Rad Laboratories, Hercules, $\mathrm{CA})$ was used to measure protein concentrations. The membrane fractions were stored at $-80^{\circ} \mathrm{C}$.

Lysyl Endopeptidase and Trypsin Digestion for Quantitative Targeted Absolute Proteomics. The plasma membrane fractions, separated membrane fractions, and whole-tissue lysates were subjected to LysC and trypsin digestion according to the reported protocol for qTAP (Uchida et al., 2013, 2015b).

Clean-Up of Peptide Samples for qTAP-Based Liquid ChromatographyTandem Mass Spectrometry Analysis. The peptide samples (equivalent to $25 \mu \mathrm{g}$ protein) were spiked with $750 \mathrm{fmol}$ of stable isotope-labeled peptides, and cleaned up as described subsequently.

For the measurement using nanoLC-TripleTOF5600: after overlaying a $200 \mu \mathrm{l}$ tip GL-SDB (GL Sciences Inc., Tokyo, Japan) on a $200 \mu \mathrm{l}$ tip GL-GC (GL Sciences Inc.), $200 \mu \mathrm{l}$ of $100 \%$ acetonitrile was added to the combined tip and centrifuged at $3000 \mathrm{~g}$ and $10^{\circ} \mathrm{C}$ for 5 minutes. Then, $200 \mu \mathrm{l}$ of $50 \%$ acetonitrile/ $50 \%$ water $/ 0.5 \%$ formic acid was added to the tips and centrifuged at $3000 \mathrm{~g}$ and $10^{\circ} \mathrm{C}$ for 5 minutes. Next, $200 \mu \mathrm{l}$ of $0.1 \%$ trifluoroacetic acid (TFA)/water was added to the tips and centrifuged at $3000 \mathrm{~g}$ and $10^{\circ} \mathrm{C}$ for 5 minutes. The peptide samples were added to the tips and centrifuged at $3000 \mathrm{~g}$ and $10^{\circ} \mathrm{C}$ for 5 minutes. Then, $200 \mu \mathrm{l}$ of $0.1 \% \mathrm{TFA} /$ water was added to the tips and centrifuged at $3000 \mathrm{~g}$ and $10^{\circ} \mathrm{C}$ for 5 minutes. The same operation was repeated two more times. Next, $200 \mu \mathrm{l}$ of $0.5 \%$ formic acid/water was added to the tips and centrifuged at $3000 \mathrm{~g}$ and $10^{\circ} \mathrm{C}$ for 5 minutes, and the same operation was performed again. After overlaying the $200 \mu \mathrm{l}$ tip GL-GC on the $200 \mu \mathrm{l}$ tip GL-SDB, $60 \mu \mathrm{l}$ of $50 \%$ acetonitrile $/ 50 \%$ water $/ 0.5 \%$ formic acid was added to the tips and centrifuged at $3000 \mathrm{~g}$ and $10^{\circ} \mathrm{C}$ for 5 minutes to elute the peptides, and the same operation was performed again.

For the measurement using microLC-QTRAP5500: after overlaying a $200 \mu \mathrm{l}$ tip GL-SDB on a $200 \mu \mathrm{l}$ tip GL-GC, $50 \mu \mathrm{l}$ of $80 \%$ acetonitrile/0.1\% TFA was added to the tips and centrifuged at $3000 \mathrm{~g}$ and $10^{\circ} \mathrm{C}$ for 5 minutes. Then, $50 \mu \mathrm{l}$ of $0.1 \% \mathrm{TFA} /$ water was added to the tips and centrifuged at $3000 \mathrm{~g}$ and $10^{\circ} \mathrm{C}$ for 5 minutes. The peptide samples were added to the tips and centrifuged at $3000 \mathrm{~g}$ and $10^{\circ} \mathrm{C}$ for 5 minutes. Next, $50 \mu \mathrm{l}$ of $0.1 \% \mathrm{TFA} /$ water was added to the tips and centrifuged at $3000 \mathrm{~g}$ and $10^{\circ} \mathrm{C}$ for 5 minutes, and the same operation was performed again. After overlaying the $200 \mu \mathrm{l}$ tip GL-GC on the $200 \mu \mathrm{l}$ tip GLSDB, $50 \mu \mathrm{l}$ of $80 \%$ acetonitrile/ $0.1 \%$ TFA was added to the tips and centrifuged at $3000 \mathrm{~g}$ and $10^{\circ} \mathrm{C}$ for 5 minutes to elute peptides, and the same operation was performed again.

The subsequent procedure was the same as for the measurement using nanoLC-TripleTOF5600 and microLC-QTRAP5500; the eluted peptide solution was dried in a centrifugal concentrator CC-105 (TOMY) under vacuum (around $40^{\circ} \mathrm{C}$ and 1 hour). The residue was reconstituted with $2 \%$ acetonitrile/ $98 \%$ water/ $0.1 \%$ formic acid and centrifuged at $15,000 \mathrm{~g}$ for 10 minutes, and the supernatant was used for liquid chromatography-tandem mass spectrometry analysis.

For the calibration curve, tryptic digests were obtained from $25 \mu \mathrm{g}$ protein of Escherichia coli lysate and spiked with unlabeled (standard) peptides $(0,5,10,15$, $20,50,100,150,750,2000$, or $4000 \mathrm{fmol}$ for the points of $0,0.2,0.4,0.6,0.8,2,4$, $6,8,30,80$, or $160 \mathrm{fmol} / \mu \mathrm{g}$ protein, respectively) and $750 \mathrm{fmol}$ of stable isotopelabeled (internal standard) peptides. The amino acid sequence of each internal standard peptide was identical to that of the corresponding standard peptide, and an amino acid residue of the internal standard peptide was labeled with stable isotopes $\left({ }^{13} \mathrm{C}\right.$ and $\left.{ }^{15} \mathrm{~N}\right)$. The calibration curve samples were acidified with TFA and cleaned up as described previously.

Quantification of Target Proteins in qTAP-Based Liquid ChromatographyTandem Mass Spectrometry Analysis. The measurements of the plasma membrane fractions and whole-tissue lysates of leptomeninges and choroid plexus were performed by parallel reaction monitoring using the nanoLC-TripleTOF5600 system (SCIEX, Framingham, MA) or by selected reaction monitoring using the microLC-QTRAP5500 system (SCIEX), as previously reported (Sadiq et al., 2015; Uchida et al., 2019). The measurements of the separated membrane fractions of leptomeninges were performed in the sequential window acquisition of all theoretical (SWATH) fragment ion spectra mode as follows. The cleaned up peptide samples were injected into an Ekspert nanoLC 425 system (Eksigent Technologies, Dublin, CA) coupled with an electrospray-ionization TripleTOF5600 mass spectrometer (SCIEX), which was set up for a single direct injection. The peptides were directly loaded onto a self-packed $\mathrm{C} 18$ analytical column, prepared by packing ProntoSIL 200-3-C18 AQ beads ( $3 \mu \mathrm{m}, 200 \AA ̊$; Bischoff Chromatography, Germany) in a PicoFrit tip ( $75 \mu \mathrm{m}$ i.d.; New Objective) of $20 \mathrm{~cm}$ length. After sample loading, the peptides were separated and eluted with a linear gradient of $2 \%$ B (0 minutes), 35\% B (120 minutes), 100\% B (121-125 minutes), and 2\% B (126-155 minutes); mobile phase A, $0.1 \%$ formic acid in water, and mobile phase B, $0.1 \%$ formic acid in acetonitrile. The flow rate was $300 \mathrm{nl} / \mathrm{min}$. The eluted peptides were positively ionized and measured in the SWATH mode: SWATH window, 64 variable windows from 400 to $1200 \mathrm{~m} / z$; product ion scan range, 50-2000 $\mathrm{m} / \mathrm{z}$; declustering potential, 100; rolling collision energy value, $0.0625 \times(\mathrm{m} / \mathrm{z}$ of each SWATH window) -3.5 ; collision energy spread, 15 ; and accumulation time, 0.05 seconds for each SWATH window. In the parallel reaction monitoring, selected reaction monitoring, and SWATH modes, the target peptides listed in Supplemental Table 2 were quantified. MultiQuant software (SCIEX) was used for data analysis. Signal peaks over 1000 counts detected at the same retention time as an internal standard peptide were defined as positive. When positive peaks were observed in at least three sets of transitions, the protein molecules were considered to be expressed in the sample of interest, and the protein expression levels (femtomole per microgram protein) were calculated using the peak area ratio (native peptide/ internal standard peptide) and the calibration curve. The limit of quantification was calculated as described previously (Uchida et al., 2015b).

Unit Conversion of Protein Expression Level from Femtomole per Microgram Protein to Picomole per Pig Cerebrum. It is necessary to compare the absolute abundances of transporters in the $\mathrm{BAB}$ and BCSFB in one porcine cerebrum to understand and compare the physiologic and pharmacologic roles of the $\mathrm{BAB}$ and $\mathrm{BCSFB}$. Here, we describe how the unit of protein expression level is converted from femtomole per microgram protein to picomole per pig cerebrum.

The recovery of plasma membrane protein of epithelial cells in the plasma membrane preparation (D) was calculated from experimental parameters (Supplemental Table 1) as follows:

$$
\mathrm{D}=\mathrm{B}_{4} / \mathrm{C}_{4}=\left(\mathrm{B}_{1} \times \mathrm{B}_{2} \times \mathrm{B}_{3} / 1000\right) /\left(\mathrm{C}_{1} \times \mathrm{C}_{2} \times \mathrm{C}_{3}\right)
$$

where $\mathrm{B}_{4}$ and $\mathrm{C}_{4}$ are the absolute amounts of the epithelial cell plasma membrane marker (AE2 or OAT1) in the total plasma membrane fraction and whole-tissue lysate, respectively (in picomoles); $\mathrm{B}_{1}$ (micrograms of protein per microliter) and $\mathrm{C}_{1}$ (milligrams of protein per milliliter) are the protein concentrations of plasma membrane fraction and whole-tissue lysate, respectively; $\mathrm{B}_{2}$ (in microliters) and $\mathrm{C}_{2}$ (in milliliters) are the solution volumes of the plasma membrane fraction and whole-tissue lysate, respectively; and $\mathrm{B}_{3}$ and $\mathrm{C}_{3}$ are the epithelial cell plasma membrane marker (AE2 or OAT1) expression levels in plasma membrane fraction and whole-tissue lysate, respectively (femtomoles per microgram of protein).

The ratio to convert the absolute amount of target protein in plasma membrane fraction to that in whole-tissue lysate (E) was calculated using D (Supplemental Table 1) as follows:

$$
\mathrm{E}=1 / \mathrm{D}
$$

The correction factor to convert the units from femtomoles per microgram of protein in the plasma membrane fraction to picomoles per gram of wet weight of choroid plexus and leptomeninges (where $\mathrm{F}$ is in milligrams of protein per gram of tissue) was calculated using the experimental parameters (Supplemental Table 1) as follows:

$$
\mathrm{F}=\left(\mathrm{B}_{1} \times \mathrm{B}_{2} \times \mathrm{E}\right) / \mathrm{A} \times 1000
$$

where $\mathrm{A}$ is the tissue weight used for plasma membrane preparation (in grams of tissue).

The protein expression level of the target protein in units of picomoles per gram of wet weight of choroid plexus and leptomeninges was calculated as follows: 
protein expression level of target protein

$=$ protein expression level in the plasma membrane fraction $\times \mathrm{F}$

where the protein expression level in the plasma membrane fraction is in units of femtomoles per microgram of protein; and $\mathrm{F}$ is in milligrams of protein per gram of tissue. The protein expression level of the target protein in units of picomole per pig cerebrum was calculated as follows:

protein expression level of target protein $=$ protein expression level $\times \mathrm{G}$

where the protein expression level is in units of picomoles per gram of wet weight of choroid plexus and leptomeninges; and $\mathrm{G}$ is the tissue weight per pig cerebrum (grams of tissue per pig cerebrum) (Supplemental Table 1). To calculate the protein expression level (picomoles per pig cerebrum) in the leptomeninges, the average of the protein expression levels (picomoles per gram of wet weight of leptomeninges) of the four regions and the tissue weight of whole leptomeninges from one cerebrum (grams of tissue per pig cerebrum) were used.

Estimation of CSF- and Blood (dura)-Facing Plasma Membrane Localization. The CSF- and blood (dura)-facing plasma membrane localizations of transporters were estimated according to our mathematical method (Kubo et al., 2015) with minor modifications. Multidrug resistance protein 1 (MDR1) localizes at the blood (dura)-facing plasma membrane (Yasuda et al., 2013). Our functional study of oat1 has shown that the elimination of para-aminohippuric acid, a substrate of oat1, from cisternal CSF was inhibited by the oat1 inhibitors cephalothin and ceftriaxone 15 minutes after intracisternal administration, as was expected from the relationship of the cisternal CSF concentration and $\mathrm{IC}_{50}$ (oat1) of the inhibitors (Zhang et al., 2018). This suggests that oat1 is involved in the transport of para-aminohippuric acid from CSF to arachnoid epithelial cells at the CSF-facing plasma membrane. Therefore, MDR1 and OAT1 were considered as blood (dura)- and CSF-facing plasma membrane markers at the BAB, respectively, in the present localization analysis. The $\mathrm{f}_{\mathrm{csf}}$ and $\mathrm{f}_{\mathrm{blood}}$ (dura) values represent the extent of CSF- and blood (dura)-facing membrane distributions, respectively, and were calculated as follows:

$$
\begin{aligned}
\mathrm{f}_{\mathrm{csf}}=\left(\mathrm{P}_{\mathrm{csf}} / \mathrm{P}_{\mathrm{u}}\right) \times\left(\mathrm{P}_{\mathrm{u}, 1} / \mathrm{P}_{\text {blood }, 3}-\mathrm{P}_{\text {blood }, 1} \times \mathrm{P}_{\mathrm{u}, 3}\right) / \\
\left(\mathrm{P}_{\mathrm{csf}, 1} \times \mathrm{P}_{\text {blood }, 3}-\mathrm{P}_{\text {blood }, 1} \times \mathrm{P}_{\mathrm{csf}, 3}\right) \\
\mathrm{f}_{\text {blood }}=\left(\mathrm{P}_{\text {blood }} / \mathrm{Pu}\right) \times\left(\mathrm{P}_{\mathrm{u}, 3} \times \mathrm{P}_{\mathrm{csf}, 1}-\mathrm{P}_{\mathrm{csf}, 3} \times \mathrm{P}_{\mathrm{u}, 1}\right) / \\
\left(\mathrm{P}_{\mathrm{csf}, 1} \times \mathrm{P}_{\text {blood }, 3}-\mathrm{P}_{\text {blood }, 1} \times \mathrm{P}_{\mathrm{csf}, 3}\right)
\end{aligned}
$$

where $\mathrm{P}_{\mathrm{u}, 1}$ and $\mathrm{P}_{\mathrm{u}, 3}$ are the protein abundances (femtomoles per microgram of protein) of the molecule of interest in the first turbid layer between the top and $24 \%$ sucrose and the third turbid layer between $27 \%$ and $30 \%$ sucrose, respectively; $\mathrm{P}_{\mathrm{u}}$ is the total protein abundance (femtomoles per microgram of protein) of the molecule of interest in the first, second, and third turbid layers; $\mathrm{P}_{\mathrm{csf}, 1}$ and $\mathrm{P}_{\mathrm{csf}, 3}$ are the protein abundances (femtomoles per microgram of protein) of the CSF-facing membrane marker OAT1 in the first and third turbid layers, respectively; $\mathrm{P}_{\mathrm{csf}}$ is the total protein abundance (femtomoles per microgram of protein) of OAT1 in the first, second, and third turbid layers; $\mathrm{P}_{\text {blood, } 1}$ and $\mathrm{P}_{\text {blood,3 }}$ are the protein abundances (femtomoles per microgram of protein) of the bloodfacing membrane marker MDR1 in the first and third turbid layers, respectively; and $\mathrm{P}_{\text {blood }}$ is the total protein abundance (femtomoles per microgram of protein) of MDR1 in the first, second, and third turbid layers.

Statistical Analysis. Unless otherwise indicated, all data are the mean \pm S.E.M. Statistical significances of differences between two groups were determined using the Welch $t$ test and the $P$ values were adjusted by the Bonferroni method in cases of multiple testing by using $\mathrm{R}$ software version $3.5 .3 ; P$ values less than 0.05 were considered statistically significant.

\section{Results}

Unit of Femtomole per Microgram Protein: Absolute Protein Expression Levels of 34 Transporters and Six Marker Proteins in $1 \mu \mathrm{g}$ Protein of Plasma Membrane Fractions of the Choroid Plexuses in Four Different Ventricles and the Leptomeninges in Four Different Lobes of Cerebrum. To understand whether there is a difference in the transport functions of the $\mathrm{BAB}$ among the four different lobes of cerebrum and to clarify the difference in the protein expression between the $\mathrm{BAB}$ and the four ventricular BCSFB, the protein expression levels of 34 transporters (which mediate transport of a range of endogenous bioactive compounds and xenobiotics) were measured in the plasma membrane fractions of the leptomeninges isolated from the frontal, parietal, occipital, and temporal lobes and choroid plexuses isolated from the right lateral, left lateral, third, and fourth ventricles. Twenty transporters were detected and their protein expression levels were determined (Table 1). The other 14 transporters were not detected. The limits of quantification for all of the molecules are listed in Supplemental Table 3. Multidrug and toxin extrusion protein 1 (MATE1), organic cation transporter (OCT) 2, and amino acid transporter A2 were detected in the leptomeninges, but not in the choroid plexus, except for MATE1 and OCT2 in the third ventricle. On the other hand, multidrug resistance-associated protein (MRP) 1, organic aniontransporting polypeptide (OATP) 1A2, OATP3A1, and OCTN2 were detected in the choroid plexus, but not in the leptomeninges. The regional differences among the four choroid plexuses were within a 2fold range for most of the transporters, except OAT1, OAT3, and MRP4 (2.44-, 2.01-, and 2.06-fold differences, respectively). The regional differences among the four leptomeninges were also within a 2-fold range, except for MRP4 and MATE1 (2.04- and 2.92-fold differences, respectively).

To compare the extent of contamination with other cells and the purity of plasma membrane among the samples, six marker proteins were quantified (Table 1). The average of the absolute abundances of vascular endothelial cell marker platelet endothelial cell adhesion molecule 1 from the four choroid plexuses was 1.31-fold greater than that from the four leptomeninges. Astrocyte marker glial fibrillary acidic protein and neuron marker synaptophysin showed 3.72- and 1.74-fold greater expression levels in leptomeninges compared with choroid plexus, respectively, based on the average values of the four leptomeninges and the four choroid plexuses. The absolute abundances of AE2 (choroid plexus epithelial cell plasma membrane marker), $\mathrm{Na}^{+} / \mathrm{K}^{+}$-ATPase (plasma membrane marker), and $\gamma$-GTP (plasma membrane marker) were within 1.24-, 1.12-, and 1.53-fold ranges, respectively, among the four choroid plexuses. The absolute abundances of $\mathrm{Na}^{+} / \mathrm{K}^{+}$-ATPase and $\gamma$-GTP were within 1.08- and 1.22-fold ranges, respectively, among the four leptomeninges.

Absolute Protein Expression Levels of 20 Transporters and Six Marker Proteins in $1 \mathrm{~g}$ Wet Weight of Choroid Plexus in Four Different Ventricles (Picomoles per Gram of Wet Weight of Choroid Plexus) and in $1 \mathrm{~g}$ Wet Weight of Leptomeninges in Four Different Lobes of Cerebrum (Picomoles per Gram of Wet Weight of Leptomeninges). To more precisely understand the regional differences in protein expression levels, it is important to correct the values for differences in the purity of plasma membrane in the plasma membrane fraction. We chose AE2 and OAT1 as markers of the plasma membrane of epithelial cells in choroid plexus and leptomeninges, respectively (Christensen et al., 2013; Zhang et al., 2018). As described in Materials and Methods, the protein expression levels of 20 transporters and six marker proteins in units of picomoles per gram of wet weight of the choroid plexus and leptomeninges (Supplemental Table 4) were estimated using the protein expression levels of AE2 and OAT1 in the plasma membrane fraction and whole-tissue lysate (Supplemental Table 1). The differences among the four regions were within a 2-fold range for most of the molecules, except for MATE1 and glial fibrillary acidic protein, which were within 3.21- and 2.13-fold ranges, respectively, in the four leptomeninges (Supplemental Table 4).

Unit of Picomole per Pig Cerebrum: Absolute Protein Expression Levels of 20 Transporters and Six Marker Proteins in the Whole Choroid Plexuses and Whole Leptomeninges in One Porcine Cerebrum. To understand the differences in the physiologic 
TABLE 1

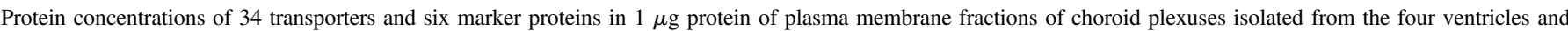
leptomeninges isolated from the four cerebral lobes (unit: femtomoles per microgram protein)

Plasma membrane fractions of porcine choroid plexus and leptomeninges were prepared from the pooled and freshly isolated choroid plexus tissues and freshly isolated leptomeninges of $10-30$

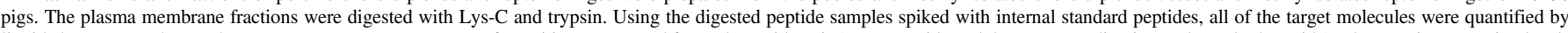

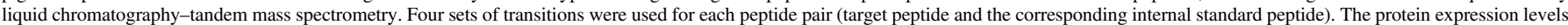

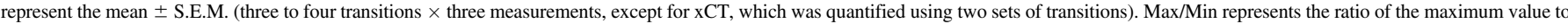
the minimum value among the four ventricular choroid plexuses, or among the leptomeninges in the four cerebral lobes. The values of the limit of quantification are shown in parenthesis.

\begin{tabular}{|c|c|c|c|c|c|c|c|c|c|c|}
\hline \multirow{4}{*}{ Molecule } & \multicolumn{10}{|c|}{ Protein Expression Level (fmol/ $\mu \mathrm{g}$ Protein) } \\
\hline & \multicolumn{5}{|c|}{ Choroid Plexus } & \multicolumn{5}{|c|}{ Leptomeninges } \\
\hline & \multicolumn{4}{|c|}{ Ventricle } & \multirow{2}{*}{$\begin{array}{l}\text { Max/ } \\
\text { Min }\end{array}$} & \multicolumn{4}{|c|}{ Lobe } & \multirow{2}{*}{$\begin{array}{l}\text { Max/ } \\
\text { Min }\end{array}$} \\
\hline & Right Lateral & Left Lateral & Third & Fourth & & Frontal & Parietal & Occipital & Temporal & \\
\hline \multicolumn{11}{|l|}{$\begin{array}{l}\text { Organic anion } \\
\text { transporters }\end{array}$} \\
\hline OAT1 & $2.23 \pm 0.11$ & $2.42 \pm 0.12$ & $5.45 \pm 0.27$ & $3.19 \pm 0.12$ & 2.44 & $30.5 \pm 1.4$ & $25.4 \pm 0.7$ & $25.5 \pm 0.8$ & $27.5 \pm 1.2$ & 1.20 \\
\hline OAT2 & ULQ $(<2.04)$ & ULQ $(<1.67)$ & ULQ $(<2.19)$ & ULQ $(<2.16)$ & - & ULQ $(<2.01)$ & ULQ $(<2.22)$ & ULQ $(<2.01)$ & ULQ $(<1.90)$ & - \\
\hline OAT3 & $1.64 \pm 0.30$ & $1.42 \pm 0.22$ & $2.07 \pm 0.15$ & $1.03 \pm 0.28$ & 2.01 & $15.6 \pm 1.1$ & $10.0 \pm 0.4$ & $10.0 \pm 0.4$ & $12.7 \pm 0.7$ & 1.56 \\
\hline OAT6 & ULQ $(<0.898)$ & ULQ $(<0.854)$ & ULQ $(<0.847)$ & ULQ $(<0.949)$ & - & ULQ $(<0.745)$ & ULQ $(<0.876)$ & ULQ $(<0.832)$ & ULQ $(<0.942)$ & - \\
\hline MRP1 & $1.69 \pm 0.14$ & $1.47 \pm 0.13$ & $1.29 \pm 0.10$ & $1.83 \pm 0.13$ & 1.41 & ULQ $(<0.887)$ & ULQ $(<0.648)$ & ULQ $(<1.12)$ & ULQ $(<1.01)$ & - \\
\hline MRP2 & ULQ $(<0.285)$ & ULQ $(<0.189)$ & $\begin{array}{c}\text { ULQ } \\
(<0.0880)\end{array}$ & ULQ $(<0.237)$ & - & ULQ $(<0.383)$ & ULQ $(<0.356)$ & $\mathrm{ULQ}(<0.262)$ & ULQ $(<0.389)$ & - \\
\hline MRP3 & $0.940 \pm 0.083$ & $0.895 \pm 0.076$ & $1.14 \pm 0.05$ & $0.867 \pm 0.084$ & 1.32 & $0.838 \pm 0.053$ & $0.748 \pm 0.054$ & $0.776 \pm 0.056$ & $0.965 \pm 0.039$ & 1.29 \\
\hline MRP4 & $0.627 \pm 0.049$ & $0.404 \pm 0.068$ & $0.834 \pm 0.059$ & $0.507 \pm 0.065$ & 2.06 & $0.927 \pm 0.041$ & $0.559 \pm 0.069$ & $1.14 \pm 0.05$ & $0.945 \pm 0.061$ & 2.04 \\
\hline OATP1A2 & $9.22 \pm 0.30$ & $8.67 \pm 0.49$ & $6.36 \pm 0.36$ & $6.67 \pm 0.41$ & 1.45 & ULQ $(<2.00)$ & ULQ (<1.45) & ULQ (<1.13) & ULQ (<1.97) & - \\
\hline OATP1B3 & ULQ $(<0.581)$ & ULQ $(<1.24)$ & ULQ $(<0.363)$ & ULQ $(<0.128)$ & - & ULQ $(<1.29)$ & ULQ $(<0.856)$ & ULQ $(<0.998)$ & ULQ $(<0.523)$ & - \\
\hline OATP2B1 & $0.665 \pm 0.063$ & $0.607 \pm 0.045$ & $0.673 \pm 0.053$ & $0.516 \pm 0.052$ & 1.30 & $0.916 \pm 0.044$ & $0.962 \pm 0.057$ & $1.02 \pm 0.05$ & $1.22 \pm 0.09$ & 1.33 \\
\hline OATP3A1 & $2.67 \pm 0.12$ & $2.25 \pm 0.11$ & $1.78 \pm 0.06$ & $1.79 \pm 0.08$ & 1.50 & ULQ $(<0.310)$ & ULQ $(<0.301)$ & ULQ $(<0.272)$ & ULQ $(<0.351)$ & - \\
\hline \multicolumn{11}{|c|}{ - ir r } \\
\hline PEPT1 & ULQ $(<0.263)$ & ULQ $(<0.277)$ & ULQ $(<0.321)$ & ULQ $(<0.277)$ & - & ULQ $(<0.321)$ & ULQ (<0.329) & ULQ $(<0.285)$ & ULQ $(<0.277)$ & - \\
\hline РЕРТ2 & $0.731 \pm 0.072$ & $0.761 \pm 0.061$ & $1.21 \pm 0.07$ & ULQ $(<0.366)$ & - & $3.29 \pm 0.20$ & $3.33 \pm 0.13$ & $3.76 \pm 0.15$ & $3.87 \pm 0.22$ & 1.18 \\
\hline \multicolumn{11}{|c|}{$\begin{array}{l}\text { Organic cation } \\
\text { transporters }\end{array}$} \\
\hline MATE1 & ULQ (<0.352) & ULQ $(<0.331)$ & $1.19 \pm 0.11$ & ULQ $(<0.146)$ & - & $5.27 \pm 0.22$ & $2.77 \pm 0.14$ & $3.36 \pm 0.10$ & $1.80 \pm 0.08$ & 2.92 \\
\hline MATE2K & ULQ $(<0.532)$ & ULQ $(<0.642)$ & ULQ (<0.110) & ULQ $(<0.137)$ & - & ULQ $(<0.560)$ & ULQ (<0.608) & ULQ $(<0.498)$ & ULQ $(<0.629)$ & - \\
\hline OCT1 & ULQ $(<0.549)$ & ULQ $(<0.545)$ & ULQ $(<0.525)$ & ULQ $(<0.552)$ & - & ULQ $(<0.582)$ & ULQ $(<0.617)$ & ULQ $(<0.558)$ & ULQ $(<0.590)$ & - \\
\hline OCT2 & ULQ $(<0.292)$ & ULQ $(<0.330)$ & $1.15 \pm 0.05$ & ULQ $(<0.211)$ & - & $11.4 \pm 0.5$ & $7.69 \pm 0.30$ & $8.25 \pm 0.27$ & $8.07 \pm 0.38$ & 1.49 \\
\hline OCT3 & ULQ $(<1.02)$ & ULQ $(<1.09)$ & ULQ $(<0.897)$ & ULQ $(<1.05)$ & - & ULQ $(<0.707)$ & ULQ $(<0.775)$ & ULQ $(<0.669)$ & ULQ $(<0.775)$ & - \\
\hline OCTN1 & ULQ $(<3.42)$ & ULQ $(<3.62)$ & ULQ $(<3.14)$ & ULQ $(<3.51)$ & - & ULQ $(<3.59)$ & ULQ $(<3.66)$ & ULQ $(<3.32)$ & ULQ $(<3.44)$ & - \\
\hline OCTN2 & $2.82 \pm 0.15$ & $2.82 \pm 0.11$ & $2.24 \pm 0.12$ & $1.99 \pm 0.14$ & 1.42 & ULQ $(<0.568)$ & ULQ $(<0.443)$ & ULQ $(<0.529)$ & ULQ $(<0.588)$ & - \\
\hline PMAT & ULQ (<2.19) & ULQ (<2.38) & ULQ (<2.57) & ULQ (<2.52) & - & ULQ $(<2.78)$ & ULQ $(<2.39)$ & ULQ $(<2.52)$ & ULQ $(<2.32)$ & - \\
\hline \multicolumn{11}{|c|}{$\begin{array}{l}\text { Lipophilic drug } \\
\text { transporters }\end{array}$} \\
\hline MDR1 & $2.53 \pm 0.12$ & $2.48 \pm 0.11$ & $3.93 \pm 0.13$ & $2.98 \pm 0.12$ & 1.58 & $5.57 \pm 0.34$ & $5.81 \pm 0.23$ & $5.11 \pm 0.18$ & $5.20 \pm 0.32$ & 1.14 \\
\hline BCRP & $1.66 \pm 0.13$ & $1.39 \pm 0.15$ & $2.71 \pm 0.11$ & $1.82 \pm 0.18$ & 1.95 & $7.69 \pm 0.29$ & $7.65 \pm 0.28$ & $7.71 \pm 0.25$ & $8.34 \pm 0.28$ & 1.09 \\
\hline \multicolumn{11}{|c|}{$\begin{array}{l}\text { Transporters for } \\
\text { energy-related } \\
\text { compounds }\end{array}$} \\
\hline GLUT1 & $24.3 \pm 0.7$ & $21.4 \pm 1.1$ & $20.3 \pm 0.3$ & $22.7 \pm 0.3$ & 1.20 & $27.0 \pm 0.3$ & $32.1 \pm 0.8$ & $30.3 \pm 2.0$ & $25.2 \pm 0.9$ & 1.27 \\
\hline MCT1 & $2.73 \pm 0.40$ & $2.63 \pm 0.11$ & $3.13 \pm 0.16$ & $2.44 \pm 0.11$ & 1.28 & $2.98 \pm 0.21$ & $3.66 \pm 0.11$ & $3.59 \pm 0.34$ & $3.37 \pm 0.18$ & 1.23 \\
\hline MCT2 & ULQ (<1.43) & ULQ (<1.49) & ULQ $(<1.37)$ & ULQ $(<1.51)$ & - & ULQ $(<1.61)$ & ULQ (<1.79) & ULQ $(<1.73)$ & ULQ $(<1.65)$ & - \\
\hline MCT3 & ULQ $(<0.798)$ & ULQ $(<0.886)$ & ULQ $(<0.644)$ & ULQ $(<0.759)$ & - & ULQ $(<0.764)$ & ULQ (<1.03) & ULQ $(<0.864)$ & ULQ $(<0.932)$ & - \\
\hline MCT4 & ULQ $(<1.31)$ & ULQ $(<1.30)$ & ULQ $(<1.12)$ & ULQ $(<1.19)$ & - & ULQ $(<1.25)$ & ULQ (<1.35) & ULQ $(<1.32)$ & ULQ $(<1.17)$ & - \\
\hline \multicolumn{11}{|l|}{$\begin{array}{l}\text { Amino acid } \\
\text { transporters }\end{array}$} \\
\hline $\mathrm{xCT}$ & $2.06 \pm 0.15$ & $1.91 \pm 0.01$ & $3.04 \pm 0.17$ & $2.67 \pm 0.40$ & 1.59 & $13.3 \pm 0.5$ & $16.5 \pm 0.4$ & $14.9 \pm 0.7$ & $18.4 \pm 0.5$ & 1.39 \\
\hline $4 \mathrm{~F} 2 \mathrm{hc}$ & $6.31 \pm 0.36$ & $6.15 \pm 0.16$ & $10.5 \pm 0.4$ & $9.59 \pm 0.26$ & 1.71 & $27.4 \pm 0.3$ & $31.4 \pm 0.4$ & $28.0 \pm 0.9$ & $35.1 \pm 0.3$ & 1.28 \\
\hline ATA2 & ULQ $(<1.17)$ & ULQ $(<1.11)$ & ULQ $(<1.26)$ & ULQ $(<1.00)$ & - & $2.10 \pm 0.13$ & $2.09 \pm 0.34$ & ULQ $(<1.43)$ & $2.14 \pm 0.16$ & - \\
\hline \multicolumn{11}{|l|}{$\begin{array}{l}\text { Thyroid } \\
\text { hormone } \\
\text { transporters }\end{array}$} \\
\hline MCT8 & $1.73 \pm 0.09$ & $1.67 \pm 0.05$ & $1.51 \pm 0.04$ & $1.47 \pm 0.07$ & 1.18 & $1.95 \pm 0.11$ & $2.40 \pm 0.09$ & $2.20 \pm 0.08$ & $2.05 \pm 0.03$ & 1.23 \\
\hline OATP1C1 & ULQ $(<3.27)$ & ULQ $(<2.85)$ & ULQ $(<2.44)$ & ULQ $(<2.59)$ & - & ULQ $(<2.67)$ & ULQ $(<2.80)$ & ULQ $(<2.01)$ & ULQ $(<1.74)$ & - \\
\hline \multicolumn{11}{|l|}{$\begin{array}{l}\text { Vascular } \\
\text { endothelial } \\
\text { cell marker }\end{array}$} \\
\hline $\begin{array}{c}\text { PECAM1 } \\
\text { Astrovte ma }\end{array}$ & $3.32 \pm 0.04$ & $3.34 \pm 0.18$ & $4.03 \pm 0.19$ & $3.35 \pm 0.19$ & 1.21 & $2.64 \pm 0.19$ & $3.17 \pm 0.22$ & $2.15 \pm 0.12$ & $2.77 \pm 0.14$ & 1.48 \\
\hline $\begin{array}{l}\text { Astrocyte ma } \\
\text { GFAP }\end{array}$ & $3.40 \pm 0.19$ & & & & 199 & & & & & \\
\hline Neuron mark & & $5.15-0.10$ & & & 1.99 & & & & . 0 & 1.03 \\
\hline SYP & $2.68 \pm 0.22$ & $2.15 \pm 0.25$ & $2.00 \pm 0.21$ & $2.28 \pm 0.23$ & 1.34 & $4.50 \pm 0.32$ & $3.54 \pm 0.27$ & $3.98 \pm 0.35$ & $3.85 \pm 0.25$ & 1.27 \\
\hline $\begin{array}{l}\text { Choroid plex } \\
\text { epithelial c } \\
\text { marker }\end{array}$ & & & & & & & & & & \\
\hline $\mathrm{AE} 2$ & $28.4 \pm 0.4$ & $25.4 \pm 2.1$ & $25.3 \pm 1.5$ & $31.4 \pm 0.7$ & 1.24 & ULQ $(<2.69)$ & ULQ $(<2.25)$ & ULQ $(<1.96)$ & ULQ $(<2.18)$ & - \\
\hline
\end{tabular}


TABLE 1-Continued

\begin{tabular}{|c|c|c|c|c|c|c|c|c|c|c|}
\hline \multirow{4}{*}{ Molecule } & \multicolumn{10}{|c|}{ Protein Expression Level (fmol $/ \mu \mathrm{g}$ Protein) } \\
\hline & \multicolumn{5}{|c|}{ Choroid Plexus } & \multicolumn{5}{|c|}{ Leptomeninges } \\
\hline & \multicolumn{4}{|c|}{ Ventricle } & \multirow{2}{*}{$\begin{array}{l}\text { Max/ } \\
\text { Min }\end{array}$} & \multicolumn{4}{|c|}{ Lobe } & \multirow{2}{*}{$\begin{array}{c}\text { Max/ } \\
\text { Min }\end{array}$} \\
\hline & Right Lateral & Left Lateral & Third & Fourth & & Frontal & Parietal & Occipital & Temporal & \\
\hline \multicolumn{11}{|c|}{$\begin{array}{l}\text { Plasma } \\
\text { membrane } \\
\text { markers }\end{array}$} \\
\hline $\begin{array}{l}\mathrm{Na}^{+} / \mathrm{K}^{+}- \\
\text {ATPase }\end{array}$ & $203 \pm 8$ & $190 \pm 9$ & $207 \pm 8$ & $184 \pm 10$ & 1.12 & $248 \pm 12$ & $229 \pm 18$ & $233 \pm 14$ & $236 \pm 13$ & 1.08 \\
\hline$\gamma$-GTP & $7.36 \pm 0.34$ & $6.60 \pm 0.08$ & $5.95 \pm 0.18$ & $4.79 \pm 0.36$ & 1.53 & $3.09 \pm 0.12$ & $3.77 \pm 0.12$ & $3.14 \pm 0.19$ & $3.10 \pm 0.08$ & 1.22 \\
\hline
\end{tabular}

monoamine transporter; SYP, synaptophysin; ULQ, under the limit of quantification.

and pharmacologic roles of $\mathrm{BAB}$ and $\mathrm{BCSFB}$ in cerebrum per one pig, we need to compare the absolute abundances of transporters in the whole BAB and the whole BCSFB in one porcine cerebrum. The protein expression level (picomoles per pig cerebrum) of a target protein at the BAB of whole cerebrum (Table 2) was estimated by multiplying the tissue weight of whole leptomeninges from one cerebrum (Supplemental Table 1) by the average of the four regional protein expression levels in units of picomoles per gram of wet weight of leptomeninges (Supplemental Table 4). To estimate the total protein expression level (picomoles per pig cerebrum) of a target protein in the four choroid plexuses (Table 2), the protein expression level in units of picomoles per gram of wet weight of choroid plexus (Supplemental Table 4) was multiplied by the tissue weight of the choroid plexus per pig cerebrum in each ventricle (Supplemental Table 1), and then summed over the four choroid plexuses. The protein expression levels (picomoles per pig cerebrum) of OCT2, MATE1, OAT1, OAT3, xCT, peptide transporter (PEPT) 2, BCRP, and MDR1 in the whole leptomeninges were 89.8-, 32.8-, 8.94-, 7.76-, 6.50-, 5.79-, 4.29-, and 1.84-fold greater than those in the whole choroid plexuses, respectively (Table 2). The level of 4F2hc, which is an anchor protein of xCT, glucose transporter 1 (GLUT1), large amino acid transporter 1, etc., was 3.77-fold greater in leptomeninges than that in the choroid plexus. MRP4, OATP2B1, monocarboxylate transporter (MCT) 8, GLUT1, and MCT1 proteins were also significantly more abundant in the whole leptomeninges than in the whole choroid plexuses, but their leptomeninges/choroid plexus ratios were each within a 1.58-fold range.

The Distribution of 14 Transporters and Two Marker Proteins in CSF- and Blood (dura)-Facing Plasma Membrane at the BAB of Porcine Cerebrum. Parameters $\mathrm{f}_{\mathrm{csf}}$ and $\mathrm{f}_{\text {blood (dura) }}$ describe the degree of distribution of target proteins in the CSF- and blood (dura)-facing plasma membranes, respectively. As described in Materials and Methods, these parameters were estimated using the protein abundances of target proteins in the three separated membrane fractions and those of the blood-facing membrane marker MDR1 and CSF-facing membrane marker OAT1 (Table 3). This localization estimation method using the protein abundances has been previously established and its mathematical method has been described in detail (Kubo et al., 2015). In a plot of the two parameters (Fig. 1), OAT3, MRP3, PEPT2, OCT2, MCT1, MCT4, xCT, and MCT8 were located near OAT1, while MRP4, OATP2B1, MATE1, BCRP, and GLUT1 were located near MDR1. 4F2hc was positioned in the middle of OAT1 and MDR1. When the plot was divided into regions, as shown by the broken lines in Fig. 1, the vascular endothelial cell marker platelet endothelial cell adhesion molecule 1 and astrocyte marker glial fibrillary acidic protein were located in different regions from the transporters estimated to be distributed in the CSF- or blood-facing plasma membranes (Fig. 1).

\section{Discussion}

The present study is the first to establish the polarized localization and absolute abundance of transporters at the $\mathrm{BAB}$ in porcine cerebrum (Fig. 2). Using MDR1 and OAT1 as blood (dura)-facing and CSF-facing plasma membrane marker proteins, respectively, we found that BCRP, MRP4, OATP2B1, MATE1, and GLUT1 localize at the blood-facing plasma membrane, while OAT3, PEPT2, MRP3, OCT2, xCT, MCT1, MCT4, and MCT8 localize at the CSF-facing plasma membrane. 4F2hc was expressed in both membranes. For OAT1, OAT3, MDR1, BCRP, PEPT2, xCT, MATE1, OCT2, and 4f2hc, absolute protein expression levels in the whole $\mathrm{BAB}$ surrounding the entire cerebrum were much greater than the total amounts in the choroid plexuses. Although MRP4, OATP2B1, MCT8, GLUT1, and MCT1 proteins were also statistically significantly more abundant in the $\mathrm{BAB}$ than the choroid plexuses per porcine cerebrum, they were almost equally distributed between the two barriers. These results demonstrate the importance of transport functions at the BAB compared with choroid plexus consisting of BCSFB. They also enable us to quantitatively understand the transport directions of individual transporters and the rank order of transport activity among different transporters at the BAB.

The elimination of organic anionic neurotoxins from the CNS is essential to maintain the homeostasis of brain function. We have previously shown that organic anion transporters at the BBB eliminate anionic neurotoxins such as the major catecholamine metabolite homovanillic acid and uremic toxins in rodents (Mori et al., 2003; Deguchi et al., 2006). However, in contrast to rodents, protein expression of OAT, OATP, and MRP family members at the BBB of large animals, including human beings, has either not been detected or has been detected at only extremely low levels compared with rodents (Uchida et al., 2011; Zhang et al., 2017). We also reported that the protein expression levels of these anion transporters in the choroid plexus were smaller in human than in rat (Uchida et al., 2015b). In contrast, our present results show that OAT1 and OAT3 are abundantly expressed in the leptomeninges of porcine cerebrum, and their levels (27.2 and $12.1 \mathrm{fmol} / \mu \mathrm{g}$ protein) (Table 1) are 9.97- and 1.82-fold greater than those reported in rat leptomeninges, respectively (Zhang et al., 2018). Furthermore, as shown in Table 2, OAT1 and OAT3 were 8.94and 7.76-fold more abundant in the whole BAB than in the total choroid plexuses per porcine cerebrum, respectively. These results suggest that the contribution of $\mathrm{BAB}$ to the elimination of organic anions from CNS is large in pig compared with rodent. Because homovanillic acid is selectively transported by human OAT1 (Shen et al., 2018), it has been 
TABLE 2

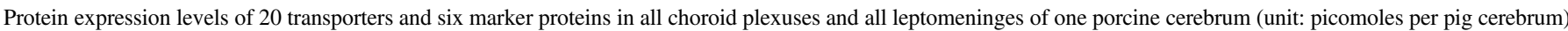

The protein expression levels (picomoles per pig cerebrum) in the choroid plexus of each ventricle and all of the choroid plexuses and leptomeninges of one porcine cerebrum were calculated using

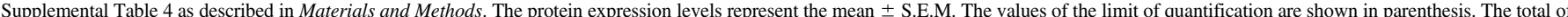

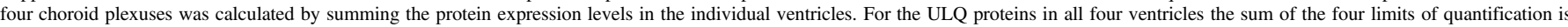

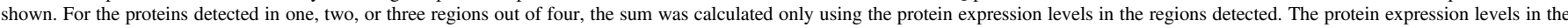

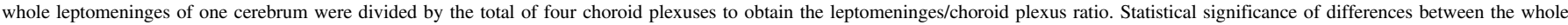
leptomeninges and total choroid plexuses was determined using the Welch t-test; the P values were adjusted by the Bonferroni method.

\begin{tabular}{|c|c|c|c|c|c|c|c|c|}
\hline \multirow{4}{*}{ Molecule } & \multicolumn{6}{|c|}{ Protein Expression Level (pmol/Pig Cerebrum) } & \multirow{4}{*}{$\begin{array}{l}\text { Leptomeninges / } \\
\text { Choroid Plexus } \\
\text { Ratio }\end{array}$} & \multirow{4}{*}{$\begin{array}{l}\text { Bonferroni- } \\
\text { Adjusted } P \\
\quad \text { Value }\end{array}$} \\
\hline & \multicolumn{5}{|c|}{ Choroid Plexus } & \multirow{3}{*}{$\begin{array}{l}\text { Whole Leptomeninges } \\
\text { of One Cerebrum }\end{array}$} & & \\
\hline & \multicolumn{4}{|c|}{ Ventricle } & \multirow{2}{*}{$\begin{array}{c}\text { Total of four Choroid } \\
\text { Plexuses }\end{array}$} & & & \\
\hline & Right Lateral & Left Lateral & Third & Fourth & & & & \\
\hline \multicolumn{9}{|l|}{$\begin{array}{l}\text { Organic anion } \\
\text { transporters }\end{array}$} \\
\hline OAT1 & $3.37 \pm 0.17$ & $4.01 \pm 0.20$ & $2.13 \pm 0.10$ & $4.46 \pm 0.17$ & $14.0 \pm 0.2$ & $125 \pm 3$ & 8.94 & $<0.001$ \\
\hline OAT3 & $2.47 \pm 0.45$ & $2.34 \pm 0.37$ & $0.811 \pm 0.059$ & $1.44 \pm 0.40$ & $7.06 \pm 0.35$ & $54.8 \pm 1.8$ & 7.76 & $<0.001$ \\
\hline MRP1 & $2.55 \pm 0.20$ & $2.43 \pm 0.22$ & $0.506 \pm 0.038$ & $2.56 \pm 0.18$ & $8.04 \pm 0.18$ & ULQ $(<5.62)$ & $<0.699$ & - \\
\hline MRP3 & $1.42 \pm 0.13$ & $1.48 \pm 0.13$ & $0.448 \pm 0.018$ & $1.21 \pm 0.12$ & $4.56 \pm 0.11$ & $3.80 \pm 0.12$ & 0.833 & $<0.001$ \\
\hline MRP4 & $0.945 \pm 0.074$ & $0.669 \pm 0.113$ & $0.327 \pm 0.023$ & $0.710 \pm 0.091$ & $2.65 \pm 0.08$ & $4.07 \pm 0.21$ & 1.54 & $<0.001$ \\
\hline OATP1A2 & $13.9 \pm 0.5$ & $14.3 \pm 0.8$ & $2.49 \pm 0.14$ & $9.34 \pm 0.58$ & $40.1 \pm 0.6$ & ULQ $(<8.43)$ & $<0.210$ & - \\
\hline OATP2B1 & $1.00 \pm 0.09$ & $1.00 \pm 0.07$ & $0.264 \pm 0.021$ & $0.722 \pm 0.073$ & $2.99 \pm 0.07$ & $4.72 \pm 0.16$ & 1.58 & $<0.001$ \\
\hline OATP3A1 & $4.02 \pm 0.18$ & $3.72 \pm 0.17$ & $0.699 \pm 0.024$ & $2.51 \pm 0.12$ & $10.9 \pm 0.1$ & ULQ $(<1.63)$ & $<0.149$ & - \\
\hline \multicolumn{9}{|l|}{ Peptide transporters } \\
\hline PEPT2 & $1.10 \pm 0.11$ & $1.26 \pm 0.10$ & $0.473 \pm 0.027$ & ULQ $(<0.512)$ & $2.83 \pm 0.09$ & $16.4 \pm 0.5$ & 5.79 & $<0.001$ \\
\hline \multicolumn{9}{|l|}{$\begin{array}{l}\text { Organic cation } \\
\text { transporters }\end{array}$} \\
\hline MATE1 & ULQ $(<0.530)$ & ULQ $(<0.548)$ & $0.464 \pm 0.042$ & ULQ $(<0.204)$ & $0.464 \pm 0.042$ & $15.2 \pm 0.9$ & 32.8 & $<0.001$ \\
\hline OCT2 & ULQ $(<0.440)$ & ULQ $(<0.546)$ & $0.452 \pm 0.021$ & ULQ $(<0.295)$ & $0.452 \pm 0.021$ & $40.6 \pm 1.2$ & 89.8 & $<0.001$ \\
\hline OCTN2 & $4.26 \pm 0.22$ & $4.67 \pm 0.18$ & $0.879 \pm 0.045$ & $2.78 \pm 0.19$ & $12.6 \pm 0.2$ & ULQ $(<2.65)$ & $<0.211$ & - \\
\hline \multicolumn{9}{|l|}{$\begin{array}{l}\text { Lipophilic drug } \\
\text { transporters }\end{array}$} \\
\hline MDR1 & $3.81 \pm 0.17$ & $4.11 \pm 0.18$ & $1.54 \pm 0.05$ & $4.17 \pm 0.17$ & $13.6 \pm 0.1$ & $25.1 \pm 0.9$ & 1.84 & $<0.001$ \\
\hline BCRP & $2.50 \pm 0.20$ & $2.30 \pm 0.25$ & $1.06 \pm 0.04$ & $2.55 \pm 0.25$ & $8.42 \pm 0.20$ & $36.1 \pm 0.9$ & 4.29 & $<0.001$ \\
\hline \multicolumn{9}{|l|}{$\begin{array}{l}\text { Transporters for } \\
\text { energy-related } \\
\text { compounds }\end{array}$} \\
\hline GLUT1 & $36.6 \pm 1.0$ & $35.4 \pm 1.7$ & $7.94 \pm 0.13$ & $31.8 \pm 0.4$ & $112 \pm 1$ & $134 \pm 8$ & 1.20 & $<0.05$ \\
\hline MCT1 & $4.11 \pm 0.61$ & $4.35 \pm 0.18$ & $1.23 \pm 0.06$ & $3.42 \pm 0.16$ & $13.1 \pm 0.3$ & $15.8 \pm 0.9$ & 1.21 & $<0.05$ \\
\hline \multicolumn{9}{|l|}{$\begin{array}{l}\text { Amino acid } \\
\text { transporters }\end{array}$} \\
\hline $\mathrm{xCT}$ & $3.10 \pm 0.23$ & $3.16 \pm 0.02$ & $1.19 \pm 0.07$ & $3.74 \pm 0.56$ & $11.2 \pm 0.3$ & $72.8 \pm 3.3$ & 6.50 & $<0.001$ \\
\hline $4 \mathrm{~F} 2 \mathrm{hc}$ & $9.52 \pm 0.54$ & $10.2 \pm 0.3$ & $4.11 \pm 0.15$ & $13.4 \pm 0.4$ & $37.2 \pm 0.4$ & $140 \pm 5$ & 3.77 & $<0.001$ \\
\hline ATA2 & ULQ $(<1.76)$ & ULQ $(<1.84)$ & ULQ $(<0.494)$ & ULQ $(<1.40)$ & ULQ $(<5.49)$ & $9.40 \pm 0.69$ & $>1.71$ & - \\
\hline \multicolumn{9}{|l|}{$\begin{array}{l}\text { Thyroid hormone } \\
\text { transporters }\end{array}$} \\
\hline MCT8 & $2.61 \pm 0.14$ & $2.76 \pm 0.09$ & $0.590 \pm 0.015$ & $2.05 \pm 0.09$ & $8.01 \pm 0.10$ & $10.0 \pm 0.6$ & 1.25 & $<0.05$ \\
\hline \multicolumn{9}{|l|}{$\begin{array}{l}\text { Vascular endothelial } \\
\text { cell marker }\end{array}$} \\
\hline PECAM1 & $5.00 \pm 0.06$ & $5.52 \pm 0.30$ & $1.58 \pm 0.07$ & $4.69 \pm 0.27$ & $16.8 \pm 0.2$ & $12.4 \pm 0.8$ & 0.740 & $<0.001$ \\
\hline \multicolumn{9}{|l|}{ Astrocyte marker } \\
\hline GFAP & $5.13 \pm 0.29$ & $6.18 \pm 0.16$ & $2.41 \pm 0.06$ & $9.46 \pm 0.47$ & $23.2 \pm 0.3$ & $87.8 \pm 8.0$ & 3.79 & $<0.001$ \\
\hline \multicolumn{9}{|l|}{ Neuron marker } \\
\hline SYP & $4.03 \pm 0.33$ & $3.55 \pm 0.42$ & $0.785 \pm 0.082$ & $3.19 \pm 0.32$ & $11.6 \pm 0.3$ & $18.2 \pm 0.8$ & 1.58 & $<0.001$ \\
\hline \multicolumn{9}{|l|}{$\begin{array}{l}\text { Choroid plexus } \\
\text { epithelial cell } \\
\text { marker }\end{array}$} \\
\hline AE2 & $42.9 \pm 0.7$ & $42.0 \pm 3.4$ & $9.92 \pm 0.59$ & $44.0 \pm 1.0$ & $139 \pm 2$ & ULQ $(<12.2)$ & $<0.0878$ & - \\
\hline \multicolumn{9}{|l|}{$\begin{array}{l}\text { Plasma membrane } \\
\text { markers }\end{array}$} \\
\hline $\mathrm{Na}^{+} / \mathrm{K}^{+}$-ATPase & $305 \pm 11$ & $314 \pm 14$ & $81.0 \pm 3.0$ & $258 \pm 14$ & $958 \pm 12$ & $1074 \pm 37$ & 1.12 & $<0.005$ \\
\hline$\gamma$-GTP & $11.1 \pm 0.5$ & $10.9 \pm 0.1$ & $2.33 \pm 0.07$ & $6.71 \pm 0.50$ & $31.1 \pm 0.4$ & $15.3 \pm 0.9$ & 0.492 & $<0.001$ \\
\hline
\end{tabular}

ATA2, amino acid transporter A2; GFAP, glial fibrillary acidic protein; PECAM1, platelet endothelial cell adhesion molecule 1; SYP, synaptophysin; ULQ, under the limit of quantification.

identified as an endogenous biomarker to quantify the in vivo transport activity of OAT1. In dog, the concentration of homovanillic acid in cisterna magna is 28 -fold smaller than that in brain ventricles, and is increased by 8 -fold by oral administration of probenecid, an inhibitor of OAT1 (Guldberg et al., 1966). By contrast, probenecid did not increase the ventricular concentration very much (1.5-fold) (Guldberg et al., 1966). These results support the idea that the transport activity of OAT1 is much larger at the BAB compared with the choroid plexus, although we cannot rule out the possibility that the probenecid concentration after oral administration is higher in cisternal CSF than in ventricular CSF.

PEPT2 is involved in the elimination of the sleep hormone melatonin (Huo et al., 2017), small neuropeptides (L-kyotorphin and carnosine), and peptidomimetics from CSF (Keep and Smith, 2011). The whole $\mathrm{BAB}$ per porcine cerebrum has a 5.79-fold greater expression level than the total choroid plexus per porcine cerebrum (Table 2). These results suggest that the transport function of PEPT2 at the $\mathrm{BAB}$ is greater than that at the choroid plexus in pig. Because approximately $80 \%$ of the CSF 
TABLE 3

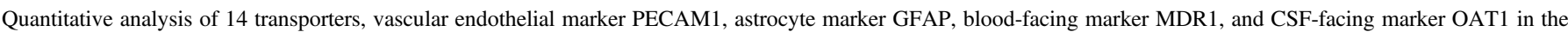
three membrane fractions separated by sucrose density gradient ultracentrifugation of cerebral leptomeninges

Leptomeninges freshly isolated from porcine cerebrum were homogenized in a Potter-Elvehjem glass homogenizer and subjected to nitrogen cavitation twice at 1500 psi for 15 minutes at $4{ }^{\circ} \mathrm{C}$. The

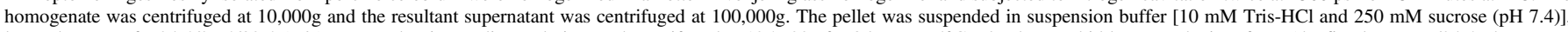

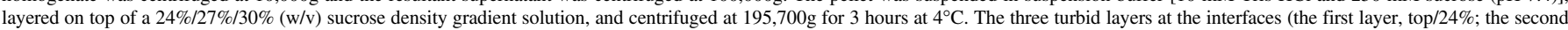

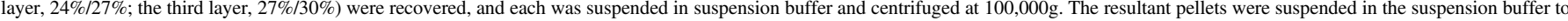

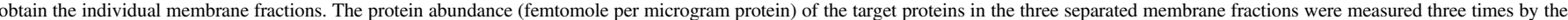
qTAP method. The values of $f_{\text {csf }}$ and $f_{\text {blood(dura) }}$ were calculated as described in Materials and Methods. The data are the mean \pm S.E.M. of three measurements.

\begin{tabular}{|c|c|c|c|c|c|c|}
\hline \multirow[b]{2}{*}{ Molecule } & \multicolumn{3}{|c|}{ Protein Abundance (fmol $/ \mu \mathrm{g}$ protein) } & \multicolumn{2}{|c|}{ Membrane Distribution } & \multirow[b]{2}{*}{$\begin{array}{l}\text { Localization } \\
\text { Determined }\end{array}$} \\
\hline & $\begin{array}{l}\text { First Turbid Layer } \\
\text { (above } 24 \% \text { Sucrose) }\end{array}$ & $\begin{array}{l}\text { Second Turbid Layer } \\
\text { (between } 24 \% \text { and } \\
27 \% \text { Sucrose) }\end{array}$ & $\begin{array}{c}\text { Third Turbid Layer } \\
\text { (between } 27 \% \text { and } \\
30 \% \text { Sucrose) }\end{array}$ & CSF-Facing $\left(\mathrm{f}_{\mathrm{csf}}\right)$ & $\begin{array}{l}\text { Blood (Dura)-Facing } \\
\quad\left(\mathrm{f}_{\text {blood (dura) }}\right)\end{array}$ & \\
\hline \multicolumn{7}{|c|}{ Organic anion transporters } \\
\hline OAT3 & $31.3 \pm 0.4$ & $33.7 \pm 0.5$ & $8.14 \pm 0.13$ & $1.12 \pm 0.02$ & $-0.229 \pm 0.014$ & CSF-facing \\
\hline MRP4 & $0.634 \pm 0.104$ & $0.696 \pm 0.085$ & $0.520 \pm 0.061$ & $-0.174 \pm 0.364$ & $1.37 \pm 0.36$ & Blood-facing \\
\hline MRP3 & $1.26 \pm 0.01$ & $1.64 \pm 0.26$ & $0.433 \pm 0.012$ & $0.834 \pm 0.080$ & $0.0450 \pm 0.0332$ & CSF-facing \\
\hline OATP2B1 & $1.36 \pm 0.23$ & $1.35 \pm 0.04$ & $0.914 \pm 0.028$ & $0.106 \pm 0.242$ & $1.07 \pm 0.23$ & Blood-facing \\
\hline \multicolumn{7}{|c|}{ Peptide transporter } \\
\hline PEPT2 & $7.99 \pm 0.11$ & $8.27 \pm 0.25$ & $2.74 \pm 0.15$ & $0.913 \pm 0.035$ & $0.0503 \pm 0.0366$ & CSF-facing \\
\hline \multicolumn{7}{|c|}{ Organic cation transporters } \\
\hline OCT2 & $23.0 \pm 0.4$ & $20.3 \pm 0.0$ & $6.92 \pm 0.16$ & $1.10 \pm 0.02$ & $-0.0976 \pm 0.0152$ & CSF-facing \\
\hline MATE1 & $1.76 \pm 0.00$ & $2.33 \pm 0.18$ & $1.40 \pm 0.05$ & $-0.0991 \pm 0.0266$ & $1.20 \pm 0.08$ & Blood-facing \\
\hline \multicolumn{7}{|c|}{ Lipophilic drug transporter } \\
\hline BCRP & $8.12 \pm 0.05$ & $14.8 \pm 0.2$ & $7.39 \pm 0.11$ & $-0.253 \pm 0.042$ & $1.25 \pm 0.05$ & Blood-facing \\
\hline \multicolumn{7}{|c|}{$\begin{array}{l}\text { Transporters for energy- } \\
\text { related compounds }\end{array}$} \\
\hline GLUT1 & $45.6 \pm 0.5$ & $66.0 \pm 1.0$ & $35.2 \pm 0.6$ & $-0.0617 \pm 0.0553$ & $1.11 \pm 0.06$ & Blood-facing \\
\hline MCT1 & $1.34 \pm 0.09$ & $1.44 \pm 0.04$ & $0.345 \pm 0.023$ & $1.13 \pm 0.06$ & $-0.241 \pm 0.023$ & CSF-facing \\
\hline MCT4 & $0.660 \pm 0.014$ & $0.489 \pm 0.060$ & $0.201 \pm 0.007$ & $1.17 \pm 0.09$ & $-0.0883 \pm 0.0596$ & CSF-facing \\
\hline \multicolumn{7}{|c|}{ Cystine transporter } \\
\hline $\mathrm{xCT}$ & $21.4 \pm 0.4$ & $26.5 \pm 0.4$ & $5.20 \pm 0.12$ & $1.09 \pm 0.01$ & $-0.271 \pm 0.007$ & CSF-facing \\
\hline 4F2hc & $93.2 \pm 1.0$ & $95.8 \pm 0.4$ & $46.0 \pm 0.1$ & $0.533 \pm 0.036$ & $0.528 \pm 0.045$ & Both sides \\
\hline \multicolumn{7}{|c|}{ Thyroid hormone transporter } \\
\hline \multicolumn{7}{|c|}{$\begin{array}{l}\text { Vascular endothelial cell } \\
\text { marker protein }\end{array}$} \\
\hline PECAM1 & $1.95 \pm 0.04$ & $3.21 \pm 0.10$ & $2.09 \pm 0.04$ & $-0.490 \pm 0.022$ & $1.60 \pm 0.05$ & - \\
\hline \multicolumn{7}{|c|}{ Astrocyte marker protein } \\
\hline GFAP & $24.6 \pm 0.4$ & $21.8 \pm 0.6$ & $9.83 \pm 0.11$ & $0.815 \pm 0.066$ & $0.253 \pm 0.059$ & - \\
\hline \multicolumn{7}{|c|}{$\begin{array}{l}\text { CSF-facing plasma } \\
\text { membrane marker } \\
\text { transporter at the } \mathrm{BAB}\end{array}$} \\
\hline OAT1 & $137 \pm 1$ & $127 \pm 1$ & $44.9 \pm 0.6$ & 1 & 0 & - \\
\hline \multicolumn{7}{|c|}{$\begin{array}{l}\text { Blood (dura)-facing plasma } \\
\text { membrane marker } \\
\text { transporter at the BAB }\end{array}$} \\
\hline MDR1 & $7.49 \pm 0.21$ & $11.6 \pm 0.4$ & $5.53 \pm 0.09$ & 0 & 1 & - \\
\hline
\end{tabular}

GFAP, glial fibrillary acidic protein; PECAM1, platelet endothelial cell adhesion molecule 1.

exists in the subarachnoid space (Thorne, 2014), more abundant expression of PEPT2 in the BAB than the BCSFB seems reasonable from the viewpoint of efficient elimination of endogenous substrates from CSF. Melatonin is secreted from the pineal gland to brain ventricles and acts on periventricular tissues to induce sleep. In sheep, the concentration of melatonin in ventricles is extremely high, while that in cisterna magna is low (Shaw et al., 1989). The low expression of PEPT2 in the choroid plexus and high expression at the BAB thus seem reasonable in terms of maintaining melatonin action in the periventricular tissues and its efficient clearance from the CNS in response to light (upon awakening).

Glucocorticoids such as cortisol are stress-responsive hormones synthesized in the adrenal cortex and are endogenous substrates of P-glycoprotein (P-gp). Because excess entry of glucocorticoids into the CNS causes neurotoxicity and decreases proliferation of nerve and hippocampus cells (Abrahám et al., 2001; Anacker et al., 2013), its penetration into CNS is limited by P-gp under normal conditions. However, in meningitis, which is an inflammation of the leptomeninges, the glucocorticoid penetrates into the inflamed leptomeninges and plays anti-inflammatory and immunomodulatory roles to suppress the meningitis. We have reported that the efflux activity of P-gp rapidly decreases during acute inflammation and oxidative stress in brain capillary endothelial cells (Hoshi et al., 2017, 2019). Therefore, decreased efflux activity of P-gp at the BAB may play a role in smoothly delivering glucocorticoids to the inflamed leptomeninges in the acute phase of meningitis.

MATE1 and OCT2 eliminate various organic cations including xenobiotics and endogenous compounds in the kidney, but have been thought not to play a major role in transport across the BAB because their expression has not been detected at the BAB thus far (Yasuda et al., 2013). Several exogenous (1-methyl-4-phenylpyridinium and tetraethylammonium) and endogenous (creatinine and NMN) cationic neurotoxins can be transported by MATE1 and OCT2 (Terada et al., 2006; Tanihara et al., 2007; Müller et al., 2015; Chu et al., 2016). In brain, creatinine is continually generated nonenzymatically from creatine in large amounts, but is eliminated from the CNS efficiently. This is important because accumulation of creatinine causes convulsions (Tachikawa et al., 2008). Since creatinine cannot be eliminated via the $\mathrm{BBB}$ and its CSF concentration is much smaller than the brain concentration in humans, it is thought to be eliminated mainly from 


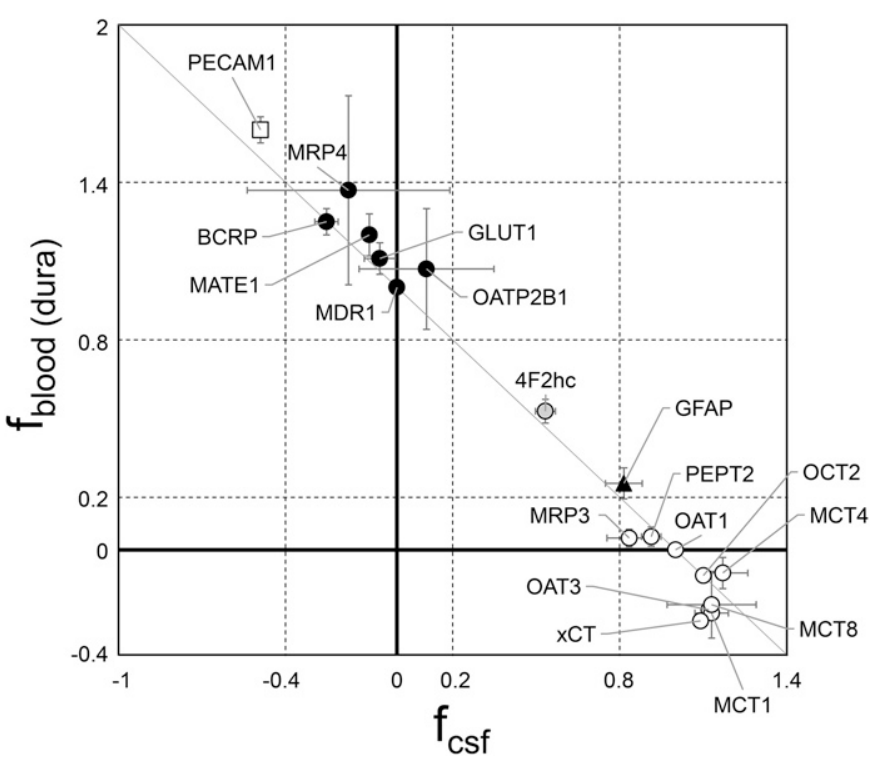

Fig. 1. Quantitative determination of the CSF- or blood (dura)-facing plasma membrane localizations at the $\mathrm{BAB}$ of porcine cerebrum for 14 transporters, vascular endothelial marker platelet endothelial cell adhesion molecule 1 (PECAM1), and astrocyte marker glial fibrillary acidic protein (GFAP). The values of $\mathrm{f}_{\mathrm{csf}}$ and $\mathrm{f}_{\text {blood(dura) }}$ were taken from Table 3 and are plotted as the mean \pm S.E.M. of three measurements. Bold lines go through the origin, and the broken lines were drawn at $-0.4,0.2,0.8$, and 1.4 on the $x$ and $y$ axes. MDR 1 is located at $\mathrm{f}_{\mathrm{blood}(\mathrm{dura})}=1$ and $\mathrm{f}_{\mathrm{csf}}=0$ as a blood (dura)-facing plasma membrane transporter. OAT1 is located at $\mathrm{f}_{\text {blood(dura) }}=0$ and $\mathrm{f}_{\mathrm{csf}}=1$ as a CSF-facing plasma membrane transporter. A solid line passes through MDR1 and OAT1. The proteins located close to $\mathrm{f}_{\text {blood(dura) }}=1$ and $\mathrm{f}_{\mathrm{csf}}=0$ should be localized at the blood (dura)-facing plasma membrane at the BAB. The proteins located close to $\mathrm{f}_{\text {blood(dura) }}=0$ and $\mathrm{f}_{\mathrm{csf}}=1$ should be localized at the CSF-facing plasma membrane at the BAB. Closed circles indicate transporters estimated to localize at the blood-facing plasma membrane. Open circles indicate transporters estimated to localize at the CSF-facing plasma membrane. The gray circle indicates $4 \mathrm{~F} 2 \mathrm{hc}$, which is expressed at both CSF- and blood-facing plasma membranes. The open square indicates the vascular endothelial cell marker PECAM1 and the closed triangle indicates the astrocyte marker GFAP.

the CSF (Tachikawa et al., 2008). OCT3 and creatine transporter 1 at the BCSFB have been considered as elimination pathways based on a rodent study (Tachikawa et al., 2008), but the protein expression levels at the BCSFB (see Table 1 for OCT3; see Uchida et al., 2015a for creatine transporter 1) are much lower than those of MATE1 and OCT2 in the leptomeninges (Table 1). Furthermore, NMN is generated from nicotinamide by nicotinamide N-methyltransferase in the CNS. Excessive production of NMN, as well as 1-methyl-4-phenylpyridinium, may be involved in the pathogenesis of Parkinson's disease, but the concentration of NMN is maintained at a low level under healthy conditions (Williams and Ramsden, 2005). The >30-fold more abundant expression levels of MATE1 and OCT2 in the leptomeninges compared with choroid plexus (Table 2) and the estimated membrane localization of these two transporters (Fig. 1; Table 3) suggest that, rather than BCSFB, MATE1 at the blood-facing membrane and OCT2 at the CSF-facing membrane at the BAB play major roles in the elimination from CSF of cationic neurotoxins produced in the CNS.

Although Yasuda et al. (2013) reported that BCRP is expressed at both CSF- and blood-facing plasma membranes, we found here that BCRP localizes at the blood-facing plasma membrane at the BAB, like MDR1 (Fig. 1; Table 3). BCRP mediates drug efflux from the brain at the luminal membrane of the BBB and drug influx into CSF in brain ventricles at the CSF-facing plasma membrane of choroid plexus epithelial cells. Knockout of the BCRP gene in mice increases the penetration of substrates into the brain while decreasing penetration into ventricular CSF (Shen et al., 2009). These results suggest that brain concentrations of substrates are regulated by $\mathrm{BCRP}$ at the $\mathrm{BBB}$, while ventricular CSF concentrations are regulated by BCRP at the BCSFB. We have already shown that the corresponding transporters at the $\mathrm{BAB}$ regulate the concentrations of substrates in cisternal CSF (Zhang et al., 2018; Yaguchi et al., 2019). The CSF-to-plasma concentration ratios of the BCRP-selective substrates daidzein and genistein in cisterna magna are 3.96- and 2.54-fold larger, respectively, in bcrp-knockout mice than in wild-type mice (Kodaira et al., 2011), and this supports the idea that BCRP limits the penetration of substrates into CSF at the blood-facing plasma membrane of the BAB. It should be noted that Yasuda et al. (2013) determined the BCRP localization by using immortalized arachnoid epithelial cells, but immortalization might have disrupted the polarized localization of BCRP since it would potentially impair cellto-cell tight junctions, which maintain the polarity of membrane transporters. However, the localization analysis in the present study still has several issues because sucrose density gradient ultracentrifugation cannot clearly separate the blood- and CSF-facing plasma membranes of arachnoid epithelial cells, and also cannot clearly separate their plasma membranes from the membrane fractions of other cells (such as pia mater, vessels, and dura mater) contained in the leptomeninges isolated at the beginning of the experiment. An electron microscopic immunogold localization study would be needed in the future to confirm the transporter localizations estimated in the present study.

It is an important issue whether the pig is an appropriate model for humans and monkeys in terms of the BAB transporters. For P-gp, the protein expression levels are within 1.5-fold difference between pigs and humans in both the brain capillaries (BBB) and choroid plexus (BCSFB) (Kubo et al., 2015; Uchida et al., 2015b) (Table 1). Based on this similarity between pigs and humans, it is plausible that the protein expression level of $\mathrm{P}-\mathrm{gp}$ is similar in pigs and humans at the $\mathrm{BAB}$ as well as the BBB and BCSFB. Because the protein expression levels of transporters in monkeys are almost the same as those in humans, e.g., at the BBB (Ohtsuki et al., 2011), the monkey BAB could also express $\mathrm{P}$-gp protein at a similar level to pig $(5.42 \mathrm{fmol} / \mu \mathrm{g}$ protein, average of four regions of leptomeninges) (Table 1). This level is 3 -fold smaller than that in the rat leptomeninges $(16.6 \mathrm{fmol} / \mu \mathrm{g}$ protein) (Zhang et al., 2018). Although P-gp gene knockout increases the CSF concentrations of P-gp substrates in rodents (Kodaira et al., 2011), the inhibition of P-gp activity does not increase the CSF concentration of nelfinavir (P-gp substrate) in monkeys (Kaddoumi et al., 2007). This can be explained by the lower protein expression level of $\mathrm{P}-\mathrm{gp}$ at the BAB in monkeys.

Regarding transporters other than P-gp at the BCSFB, many transporters such as OAT3, MRP1, MRP4, MDR1, and MCT1 have similar protein expression levels in pigs (Table 1) and humans (Uchida et al., 2015b), although some transporters such as OATP1A2 and MATE1 show large differences between pigs and humans. This suggests that the relationship of protein expression levels between the BAB and BCSFB found in the present study using pigs may be preserved in human and monkey for some transporters, although not all. Therefore, absolute quantification using the human and monkey samples will be necessary in the future to clarify the differences in the roles of the BAB and BCSFB in human and monkey.

In conclusion, the present study is the first to clarify the differences in the absolute protein abundance of transporters at the BAB and BCSFB per porcine head, as well as their membrane localizations at the BAB (Fig. 2). Our results indicate that the transport systems at the BAB may make a greater overall contribution than those at the BCSFB. This information about the transport capacities and directions of substances across the $\mathrm{BAB}$ should lead to a better understanding of the physiologic and pharmacologic roles of the $\mathrm{BAB}$. 


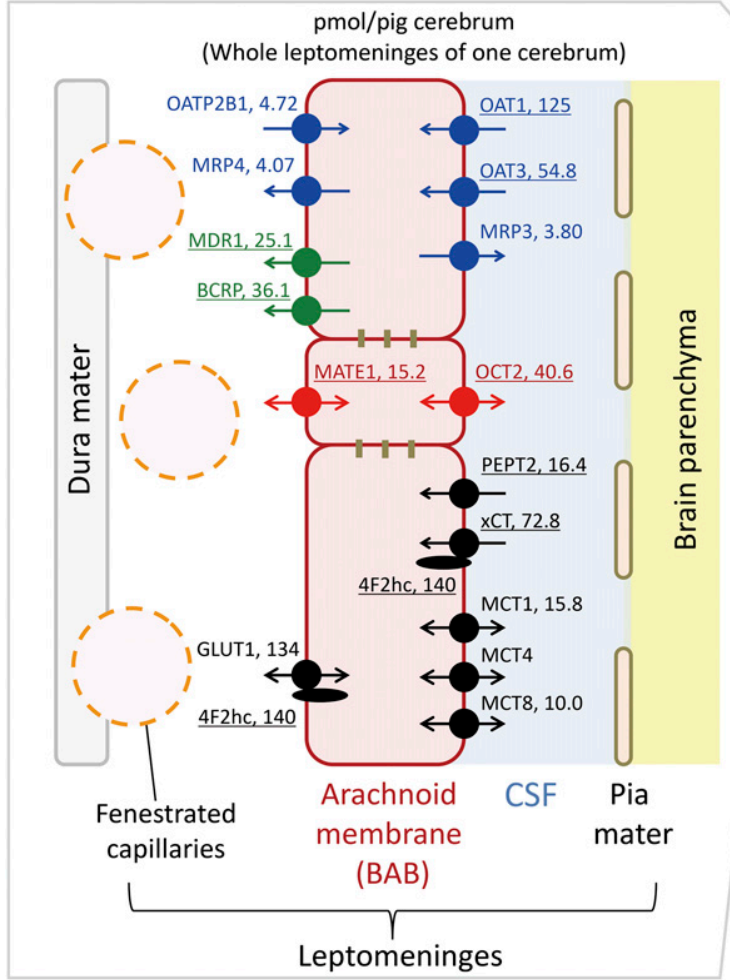

Blood-Arachnoid Barrier (BAB)

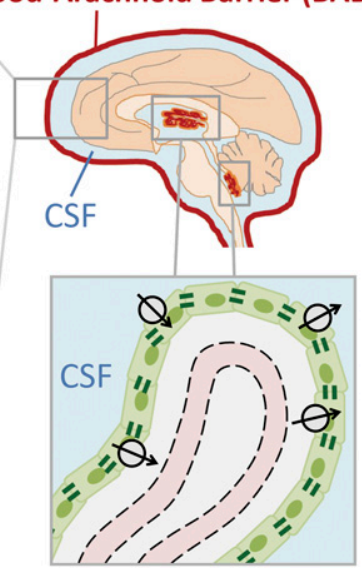

Blood-CSF Barrier (BCSFB)

$\mathrm{pmol} / \mathrm{pig}$ cerebrum

(total of 4 choroid plexus)

OAT1, 14.0 MATE1, 0.464

OAT $3,7.06 \quad$ OCT2, 0.452

MRP1, 8.04 OCTN2, 12.6

MRP3, $4.56 \quad$ PEPT2, 2.83

MRP4, 2.65 GLUT1, 112

OATP1A2, 40.1 MCT1, 13.1

OATP2B1, $2.99 \quad \mathrm{xCT}, 11.2$

OATP3A1, 10.9 4F2hc, 37.2

MDR1, 13.6 MCT8, 8.01

$B C R P, 8.42$
Fig. 2. Summary of key findings at the porcine $B A B$ and BCSFB in the present study, which illustrates the protein expression levels of transporters at the whole $\mathrm{BAB}$ and $\mathrm{BCSFB}$ in one porcine cerebrum (picomole per pig cerebrum) and the determined localizations of transporters at the blood (dura)- or CSF-facing plasma membrane of arachnoid epithelial cells. The number next to each transporter name represents the protein expression level with the unit of picomoles per pig cerebrum. The underlined transporters are $>1.8$-fold more abundantly expressed at the $\mathrm{BAB}$ than the BCSFB. The four transporters indicated in bold were detected only in the choroid plexus, but not in the leptomeninges. Blue, organic anion transporters; red, organic cation transporters; green, lipophilic drug transporters; black, endogenous compound transporters.

\section{Acknowledgments}

We thank A. Niitomi for secretarial assistance.

\section{Authorship Contributions}

Participated in research design: Uchida, Usui, Tachikawa, Terasaki. Conducted experiments: Goto, Takeuchi, Łuczak.

Contributed new reagents or analytic tools: Uchida, Goto.

Performed data analysis: Uchida, Goto, Takeuchi, Łuczak.

Wrote or contributed to the writing of the manuscript: Uchida, Goto, Terasaki.

\section{References}

Abrahám IM, Harkany T, Horvath KM, and Luiten PG (2001) Action of glucocorticoids on survival of nerve cells: promoting neurodegeneration or neuroprotection? J Neuroendocrinol 13: 749-760.

Anacker C, Cattaneo A, Luoni A, Musaelyan K, Zunszain PA, Milanesi E, Rybka J, Berry A, Cirulli F, Thuret S, et al. (2013) Glucocorticoid-related molecular signaling pathways regulating hippocampal neurogenesis. Neuropsychopharmacology 38:872-883.

Christensen IB, Gyldenholm T, Damkier HH, and Praetorius J (2013) Polarization of membrane associated proteins in the choroid plexus epithelium from normal and slc4alo knockout mice. Front Physiol 4:344.

Chu X, Bleasby K, Chan GH, Nunes I, and Evers R (2016) The complexities of interpreting reversible elevated serum creatinine levels in drug development: does a correlation with inhibition of renal transporters exist? Drug Metab Dispos 44:1498-1509.

De Deyn PP, D'Hooge R, Van Bogaert PP, and Marescau B (2001) Endogenous guanidino compounds as uremic neurotoxins. Kidney Int Suppl 78:S77-S83.

Deguchi T, Isozaki K, Yousuke K, Terasaki T, and Otagiri M (2006) Involvement of organic anion transporters in the efflux of uremic toxins across the blood-brain barrier. J Neurochem 96 1051-1059.

Guldberg HC, Ashcroft GW, and Crawford TB (1966) Concentrations of 5-hydroxyindolylacetic acid and homovanillic acid in the cerebrospinal fluid of the dog before and during treatment with probenecid. Life Sci 5:1571-1575.

Hoshi Y, Uchida Y, Tachikawa M, Ohtsuki S, Couraud PO, Suzuki T, and Terasaki T (2019) Oxidative stress-induced activation of $\mathrm{Abl}$ and Src kinases rapidly induces P-glycoprotein internalization via phosphorylation of caveolin-1 on tyrosine-14, decreasing cortisol efflux at the blood-brain barrier. J Cereb Blood Flow Metab DOI: 10.1177/0271678X18822801 [published ahead of print].

Hoshi Y, Uchida Y, Tachikawa M, Ohtsuki S, and Terasaki T (2017) Actin filament-associated protein 1 (AFAP-1) is a key mediator in inflammatory signaling-induced rapid attenuation of intrinsic P-gp function in human brain capillary endothelial cells. J Neurochem 141:247-262.

Huo X, Wang C, Yu Z, Peng Y, Wang S, Feng S, Zhang S, Tian X, Sun C, Liu K, et al. (2017) Human transporters, PEPT1/2, facilitate melatonin transportation into mitochondria of cancer cells: an implication of the therapeutic potential. J Pineal Res 62:e12390.
Kaddoumi A, Choi SU, Kinman L, Whittington D, Tsai CC, Ho RJ, Anderson BD, and Unadkat JD (2007) Inhibition of P-glycoprotein activity at the primate blood-brain barrier increases the distribution of nelfinavir into the brain but not into the cerebrospinal fluid. Drug Metab Dispos 35:1459-1462.

Kamiie J, Ohtsuki S, Iwase R, Ohmine K, Katsukura Y, Yanai K, Sekine Y, Uchida Y, Ito S, and Terasaki T (2008) Quantitative atlas of membrane transporter proteins: development and application of a highly sensitive simultaneous LC/MS/MS method combined with novel in-silico peptide selection criteria. Pharm Res 25:1469-1483.

Keep RF and Smith DE (2011) Choroid plexus transport: gene deletion studies. Fluids Barriers CNS 8:26.

Kodaira H, Kusuhara H, Fujita T, Ushiki J, Fuse E, and Sugiyama Y (2011) Quantitative evaluation of the impact of active efflux by P-glycoprotein and breast cancer resistance protein at the bloodbrain barrier on the predictability of the unbound concentrations of drugs in the brain using cerebrospinal fluid concentration as a surrogate. J Pharmacol Exp Ther 339:935-944.

Kubo Y, Ohtsuki S, Uchida Y, and Terasaki T (2015) Quantitative determination of luminal and abluminal membrane distributions of transporters in porcine brain capillaries by plasma membrane fractionation and quantitative targeted proteomics. J Pharm Sci 104:3060-3068.

Marescau B, Deshmukh DR, Kockx M, Possemiers I, Qureshi IA, Wiechert P, and De Deyn PP (1992) Guanidino compounds in serum, urine, liver, kidney, and brain of man and some ureotelic animals. Metabolism 41:526-532.

Mori S, Takanaga H, Ohtsuki S, Deguchi T, Kang YS, Hosoya K, and Terasaki T (2003) Rat organic anion transporter 3 (rOAT3) is responsible for brain-to-blood efflux of homovanillic acid at the abluminal membrane of brain capillary endothelial cells. J Cereb Blood Flow Metab 23: $432-440$.

Müller F, Pontones CA, Renner B, Mieth M, Hoier E, Auge D, Maas R, Zolk O, and Fromm MF (2015) $\mathrm{N}^{1}$-methylnicotinamide as an endogenous probe for drug interactions by renal cation transporters: studies on the metformin-trimethoprim interaction. Eur J Clin Pharmacol 71:85-94. Ohtsuki S, Ikeda C, Uchida Y, Sakamoto Y, Miller F, Glacial F, Decleves X, Scherrmann JM, Couraud PO, Kubo Y, et al. (2013) Quantitative targeted absolute proteomic analysis of transporters, receptors and junction proteins for validation of human cerebral microvascular endothelial cell line hCMEC/D3 as a human blood-brain barrier model. Mol Pharm 10:289-296.

Ohtsuki S, Schaefer O, Kawakami H, Inoue T, Liehner S, Saito A, Ishiguro N, Kishimoto W, Ludwig-Schwellinger E, Ebner T, et al. (2012) Simultaneous absolute protein quantification of transporters, cytochromes P450, and UDP-glucuronosyltransferases as a novel approach for the characterization of individual human liver: comparison with mRNA levels and activities. Drug Metab Dispos 40:83-92.

Ohtsuki S, Uchida Y, Kubo Y, and Terasaki T (2011) Quantitative targeted absolute proteomicsbased ADME research as a new path to drug discovery and development: methodology, advantages, strategy, and prospects. J Pharm Sci 100:3547-3559.

Patabendige A, Skinner RA, Morgan L, and Abbott NJ (2013) A detailed method for preparation of a functional and flexible blood-brain barrier model using porcine brain endothelial cells. Brain Res 1521:16-30.

Sadiq MW, Uchida Y, Hoshi Y, Tachikawa M, Terasaki T, and Hammarlund-Udenaes M (2015) Validation of a P-glycoprotein (P-gp) humanized mouse model by integrating selective absolute quantification of human MDR1, mouse Mdr1a and Mdrlb protein expressions with in vivo functional analysis for blood-brain barrier transport. PLoS One 10:e0118638.

Shaw PF, Kennaway DJ, and Seamark RF (1989) Evidence of high concentrations of melatonin in lateral ventricular cerebrospinal fluid of sheep. J Pineal Res 6:201-208. 
Shen H, Nelson DM, Oliveira RV, Zhang Y, Mcnaney CA, Gu X, Chen W, Su C, Reily MD, Shipkova PA, et al. (2018) Discovery and validation of pyridoxic acid and homovanillic acid as novel endogenous plasma biomarkers of organic anion transporter (OAT) 1 and OAT3 in cynomolgus monkeys. Drug Metab Dispos 46:178-188.

Shen J, Carcaboso AM, Hubbard KE, Tagen M, Wynn HG, Panetta JC, Waters CM, Elmeliegy MA, and Stewart CF (2009) Compartment-specific roles of ATP-binding cassette transporters define differential topotecan distribution in brain parenchyma and cerebrospinal fluid. Cancer Res 69:5885-5892.

Tachikawa M, Kasai Y, Takahashi M, Fujinawa J, Kitaichi K, Terasaki T, and Hosoya K (2008) The blood-cerebrospinal fluid barrier is a major pathway of cerebral creatinine clearance: involvement of transporter-mediated process. J Neurochem 107:432-442.

Tanihara Y, Masuda S, Sato T, Katsura T, Ogawa O, and Inui K (2007) Substrate specificity of MATE1 and MATE2-K, human multidrug and toxin extrusions/ $\mathrm{H}^{+}$-organic cation antiporters. Biochem Pharmacol 74:359-371.

Terada T, Masuda S, Asaka J, Tsuda M, Katsura T, and Inui K (2006) Molecular cloning, functional characterization and tissue distribution of rat $\mathrm{H}^{+}$/organic cation antiporter MATE1. Pharm Res 23:1696-1701

Thorne RG (2014) Appendix: primer on central nervous system structure/function and the vasculature, ventricular system, and fluids of the brain, in Drug Delivery to the Brain: Physiological Concepts, Methodologies and Approaches (Hammarlund-Udenaes M, de Lange EC, and Thorne RG eds) pp 685-707, Springer, New York.

Uchida Y, Ohtsuki S, Kamiie J, Ohmine K, Iwase R, and Terasaki T (2015a) Quantitative targeted absolute proteomics for 28 human transporters in plasma membrane of Caco-2 cell monolayer cultured for 2, 3, and 4 weeks. Drug Metab Pharmacokinet 30:205-208.

Uchida Y, Ohtsuki S, Katsukura Y, Ikeda C, Suzuki T, Kamiie J, and Terasaki T (2011) Quantitative targeted absolute proteomics of human blood-brain barrier transporters and receptors. I Neurochem 117:333-345.

Uchida Y, Sumiya T, Tachikawa M, Yamakawa T, Murata S, Yagi Y, Sato K, Stephan A, Ito K Ohtsuki S, et al. (2019) Involvement of claudin-11 in disruption of blood-brain, -spinal cord, and -arachnoid barriers in multiple sclerosis. Mol Neurobiol 56:2039-2056.

Uchida Y, Tachikawa M, Obuchi W, Hoshi Y, Tomioka Y, Ohtsuki S, and Terasaki T (2013) A study protocol for quantitative targeted absolute proteomics (QTAP) by LC-MS/MS: application for inter-strain differences in protein expression levels of transporters, receptors, claudin-5, and marker proteins at the blood-brain barrier in ddY, FVB, and C57BL/6J mice. Fluids Barriers CNS 10:21.

Uchida Y, Zhang Z, Tachikawa M, and Terasaki T (2015b) Quantitative targeted absolute proteomics of rat blood-cerebrospinal fluid barrier transporters: comparison with a human specimen. J Neurochem 134:1104-1115.

Walters EM, Agca Y, Ganjam V, and Evans T (2011) Animal models got you puzzled?: think pig. Ann N Y Acad Sci 1245:63-64.

Williams AC and Ramsden DB (2005) Autotoxicity, methylation and a road to the prevention of Parkinson's disease. J Clin Neurosci 12:6-11.

Yaguchi Y, Tachikawa M, Zhang Z, and Terasaki T (2019) Organic anion-transporting polypeptide 1a4 (Oatpla4/Slcola4) at the blood-arachnoid barrier is the major pathway of sulforhodamine101 clearance from cerebrospinal fluid of rats. Mol Pharm 16:2021-2027.

Yasuda K, Cline C, Vogel P, Onciu M, Fatima S, Sorrentino BP, Thirumaran RK, Ekins S, Urade Y, Fujimori K, et al. (2013) Drug transporters on arachnoid barrier cells contribute to the bloodcerebrospinal fluid barrier. Drug Metab Dispos 41:923-931.

Zhang Z, Tachikawa M, Uchida Y, and Terasaki T (2018) Drug clearance from cerebrospinal fluid mediated by organic anion transporters 1 (Slc22a6) and 3 (Slc22a8) at arachnoid membrane of rats. Mol Pharm 15:911-922.

Zhang Z, Uchida Y, Hirano S, Ando D, Kubo Y, Auriola S, Akanuma SI, Hosoya KI, Urtti A, Terasaki T, et al. (2017) Inner blood-retinal barrier dominantly expresses breast cancer resistance protein: comparative quantitative targeted absolute proteomics study of CNS barriers in pig. Mol Pharm 14:3729-3738.

Address correspondence to: Dr. Yasuo Uchida, Division of Membrane Transport and Drug Targeting, Graduate School of Pharmaceutical Sciences, Tohoku University, 6-3 Aoba, Aramaki, Aoba-ku, Sendai, 980-8578, Japan. E-mail: yasuo.uchida.c8@tohoku.ac.jp 